\title{
Albian cockroaches (Insecta, Blattida) from French amber of Archingeay
}

\author{
Peter VRŠANSKÝ \\ Geological Institute, Slovak Academy of Sciences, \\ Dúbravská c. 9, P.O. BOX 106, 84005 Bratislava (Slovakia) \\ and Paleontological Institute, Russian Academy of Sciences, \\ Profsoyuznaya 123, 117868 Moscow (Russia) \\ geolvrsa@savba.sk
}

Vršanský P. 2009. - Albian cockroaches (Insecta, Blattida) from French amber of Archingeay. Geodiversitas 31 (1): 73-98.

\begin{abstract}
The aim of the present paper is to evaluate the taxonomic composition and diversity of the richest fossil cockroach assemblage from Mesozoic amber and to compare them with those of the Mesozoic sedimentary record. The studied assemblage originated from the Late Albian (Early Cretaceous) deposit of Archingeay-Les Nouillers in southwestern France. Phase-contrast X-ray synchrotron imaging, a technique recently developed for analysing amber inclusions, is used here for the first time to reconstruct very detailed views of two cockroach specimens fossilised in a piece of opaque amber. The Blattulidae Vishniakova, 1982, here represented by Batola nikolai n. gen., n. sp. and Globula lake n. gen., n. sp. were, analogically as in sedimentary record, dominant; Liberiblattinidae Vršanský,

2002, represented by Leptolythica vincenti n. gen., n. sp.; and Mesoblattinidae Handlirsch, 1906, represented by Sivis odpo n. gen., n. sp. were subdominant; the new family Eadiidae n. fam., with Eadia aidae n. gen., n. sp. occurs only in the present and Myanmar ambers; and a new, here not described family is yet only indigenous to this locality. Caloblattinidae Vršanský \& Ansorge, 2000 are rare apparently due to their large size and thus low resin-burial potential, in spite of their fairly common occurrence in the Late Mesozoic assemblages of rock fossil. The present assemblage considerably differs from the standard conservative worldwide Early Cretaceous assemblages of imprint fossils. In spite of alternative taxonomic composition at generic level, however, and due to the particular burial conditions in amber, this association is of a comparable, rather low, specific diversity.
\end{abstract}

KEY WORDS

Insecta,

fossil cockroaches,

Blattida,

Blattaria,

Blattodea,

Blattulidae,

Mesoblattinidae,

Liberiblattinidae,

Eadiidae,

Cretaceous amber,

France,

X-ray synchrotron,

new family,

new genera,

new species. 
MOTS CLÉS

Insecta,

blattes fossiles,

Blattida,

Blattaria,

Blattodea,

Blattulidae,

Mesoblattinidae,

Liberiblattinidae, Eadiidae,

ambre crétacée, France,

rayons $\mathrm{X}$ synchrotron, famille nouvelle, genres nouveaux, espèces nouvelles.

\section{RÉSUMÉ \\ Blattes de l'ambre albien français d'Archingeay (Insecta, Blattida).}

Le but de cet article est d'évaluer la composition taxonomique et la diversité du plus riche assemblage de blattes fossiles dans l'ambre du Mésozoïque, et de les comparer avec celles des sédiments mésozoïques. L’assemblage étudié provient du gisement Albien terminal (Crétacé inférieur) d'Archingeay-Les Nouillers, dans le Sud-Ouest de la France. Deux blattes fossilisées dans un morceau d'ambre opaque sont reconstruites pour la première fois de façon très détaillée au moyen de l'imagerie en contraste de phase par rayonnement $X$ synchrotron, une technique développée récemment pour analyser les inclusions de l'ambre. Les Blattulidae Vishniakova, 1982, représentés ici par Batola nikolai n. gen., n. sp., et Globula lake n. gen., n. sp., sont numériquement dominants comme dans le registre sédimentaire; les Liberiblattinidae Vršanský, 2002, représentés par Leptolythica vincenti n. gen., n. sp., et les Mesoblattinidae Handlirsch, 1906, représentés par Sivis odpo n. gen., n. sp., sont sub-dominants; une nouvelle famille, Eadiidae n. fam., avec Eadia aidae n. gen., n. sp., est présente uniquement dans l'ambre d'Archingeay et l'ambre contemporain du Myanmar; et une nouvelle famille, non décrite ici, est endémique de ce gisement français. Les Caloblattinidae Vršanský \& Ansorge, 2000, généralement communs dans les assemblages sédimentaires du Mésozoïque supérieur, sont rares ici du fait de leur grande taille et donc d'un faible potentiel de piégeage dans la résine. L'assemblage étudié ici differe considérablement des assemblages standards d'empreintes fossiles du Crétacé inférieur. Cependant, malgré une composition taxonomique différente au niveau des genres, et du fait de conditions de préservation particulières, cette association dans l'ambre montre une diversité spécifique comparable, assez faible.

\section{INTRODUCTION}

Cockroaches are among the most common Mesozoic insect fossils, with about 30000 collected specimens ranging from the Early Triassic, up to the terminal, Campanian, Late Cretaceous (Cifuentes et al. 2006), and originating from all continents except Antarctica. They comprise up to 1500 species, some of which are preserved completely, and/or in detail scale of $0.5 \mu \mathrm{m}$ (Vršanský et al. 2001).

In this fossil record are represented various life forms such as jumping pollinators Skokidae Vršanský, 2007 (Vršanský 2007), carnivorous Raphidiomimidae Vishniakova, 1973 (Vishniakova 1973; Vršanský \& Ansorge 2007), beetle-like Umenocoleidae Chen \& Tian, 1973 (Vršanský 2003a), extremely wide Latiblattidae Vishniakova, 1968 (Vishniakova 1968), but the vast majority is of medium-sized customary, with conservative detritivorous habits in decomposition part of the food chain.
Almost all the fossils are represented by imprints, thus with an evident bias as they mainly compose the fauna from near-water more or less open habitats. Mesozoic amber individuals are extraordinarily rare: adults are known by three specimens only, one from the Turonian New Jersey amber, and two from the Hauterivian Lebanese amber. Only few nymphs are also described: two from the Lebanese amber, one from the New Jersey amber (Vršanský 2004), a nymph from the Burmese amber (Grimaldi \& Ross 2004) and a complete blattulid nymph from the Cenomanian amber of Sisteron in southeastern France (Vršanský 2008a).

Additionally, Grimaldi (2003) described Burmantis asiatica Grimaldi, 2003, another nymph that he ascribed to Mantidae Burmeister, 1838, but which was later excluded from mantises by Gorochov (2006). This specimen has cerci characteristic of the Blattulidae, which nymphs also sometimes have short foreleg coxae - a character otherwise unusual for the Dictyoptera (Gorochov 2006). 
The present study of cockroaches from the amber deposit of Archingeay, in southwestern France, is the most complete overview of an amber cockroach assemblage. It revealed 17 specimens (11 complete, two adults) (Table 1), with hundreds of new characters, unknown in imprint fossils. The most valuable difference with imprints is the $3 \mathrm{D}$ preservation, allowing appreciation of the general habitus of representatives of the Mesozoic families.

Ecologically, the assemblage considerably differs from the ones in imprints, partially in expected bias towards smaller individuals. Even when considering this difference, the taxonomic composition is distinct from that in the sedimentary record. Amber record is rich in familial diversity with two families occurring only in amber, and also conservative genera of the family Blattulidae are replaced by the indigenous genus Batola n. gen.; and the Mesoblattinidae Handlirsch, 1906 Praeblattella Vršanský, 2003 and Archimesoblatta Vršanský, 2003 are replaced by the genus Sivis n. gen. The result indicates that different Mesozoic sedimentary environments reveal similar, although not identical cockroach assemblages.

\section{MATERIAL AND METHODS}

The 17 specimens studied in the course of the present paper all originate from the amber of ArchingeayLes Nouillers, Charente-Maritime, SW France, collected in the Late Albian lithological subunit A1sl2 (sensu Néraudeau et al. 2002). The specimens were prepared according to the method described in detail by Perrichot et al. (2004), were examined and photographed using a Leica MZ12 stereomicroscope equipped with a Leica digital camera. Photographs were re-drawned using Corel-Draw X3 and Adobe Photoshop 6.0 computer programs.

Immature specimens preserved in opaque amber piece no. ARC- $037 \mathrm{~b}$ were detected and $3 \mathrm{D}$-reconstructed using phase contrast X-ray synchrotron imaging on the beamline ID19 of the European Synchrotron Radiation Facility (ESRF) at Grenoble, France. The detailed protocol for application of phase contrast X-ray microradiography and microtomography to the detection and reconstruction of amber inclusions is given in Lak et al.
TABLE 1. - Taphonomy of the Archingeay amber. Family indet. is the specimen ARC-309.2 (Fig. 3, individual below).

\begin{tabular}{lcccc}
\hline Specimens/species & Larvae & Adults & Legs & Total \\
\hline Caloblattinidae indet. & 0 & 0 & 1 & 1 \\
Batola nikolai n. gen., n. sp. & 4 & 1 & 2 & 7 \\
Globula Lake n. gen., n. sp. & 2 & 0 & 1 & 3 \\
Leptolythica vincenti n. gen., n. sp. & 1 & 0 & 0 & 1 \\
Family indet. n. fam., n.gen., n. sp. & 0 & 1 & 0 & 1 \\
Eadia aidae n. gen., n. sp. & 1 & 0 & 0 & 1 \\
Sivis odpo n. gen., n. sp. & 2 & 0 & 0 & 2 \\
Family indet. & 1 & 0 & 0 & 1 \\
\hline Total & 11 & 2 & 4 & 17 \\
\hline
\end{tabular}

(2008). All specimens are deposited in the amber collection of the Muséum national d'Histoire naturelle, Paris.

$\begin{array}{ll}\text { ABBREVIATIONS } \\ \text { A } & \text { anal veins; } \\ \text { CuA } & \text { cubitus anterior; } \\ \text { CuP } & \text { cubitus posterior; } \\ \text { M } & \text { media; } \\ \text { R } & \text { radius; } \\ \text { RS } & \text { radius sector; } \\ \text { Sc } & \text { subcosta; } \\ \text { L } & \text { left; } \\ \text { R } & \text { right. }\end{array}$

\section{SYSTEMATICS}

Order BLATTIDA Latreille, 1810

Superfamily BLATTULOIDEA Vishniakova, 1982 sensu Vršanský (2008b)

Family BLATTULIDAE Vishniakova, 1982

DIAGNOSIS. - Usually small species (forewing usually well under $10 \mathrm{~mm}$, extremely rarely $17 \mathrm{~mm}$ ). Head globular, eyes projected more or less within outline of the head. Occiput usually with two distinct dark stripes. Antennal segments bearing a set of transversal ridges and five to seven subapical sensilla chaetica about as long as half segment length. Maxillary palp short and robust. Body thick, cerci with few segments bearing extremely long sensilla chaetica; styli present. Female with short external ovipositor. Wings with plain dark veins and more pale plain intercalaries, usually with cross-veins. Sc simple; RS not differentiated; A simple. Hindwing with comb-like R1, differentiated RS, usually with simply branched $\mathrm{CuA}$, simple $\mathrm{CuP}$ and curved and branched A1. Pleating is not veer-like. 


\section{Genus Batola n. gen.}

TyPe SPECIES. - Batola nikolai n. sp., by monotypy.

ETYMOLOGY. - After batola (Slavic for newborn) sustaining the suffix -la for the genera of the family Blattulidae; gender feminine.

DifFERENTIAL DiAGNOSIs. - The present genus may be categorized within Blattulidae based on its characteristic small habitus, and the character of wing venation with plain dark main branches and wide more pale, brown, intercalaries.

It differs from all genera except Xonpepetla CifuentesRuiz \& Vršanský, 2006; Vrtula Vršanský, 2008; Elisama Giebel, 1856 and Eublattula Handlirsch, 1939 (i.e. Blattula Handlirsch, 1906; Tarakanula Vršanský, 2003; Svabula Vršanský, 2005; Kridla Vršanský, 2005; Habroblattula Wang, Liang \& Ren, 2007; Macaroblattula Wang, Ren \& Liang, 2007; Nula Vršanský, 2008) in being robust (see also Wang et al. 2007a, b).

Xonpepetla differs in having wing bases more approximated, having expanded $\mathrm{M}$ and not sharply curved posterior wing base (all plesiomorphies).

Vrtula is a significantly elongated, large and aberrant taxon; Eublattula is a primitive taxon with modified venation.

The most closely related appears to be Elisama with similar but less expanded coloration (plesiomorphy) and identical head coloration (synapomorphy). The shape of the wing with gradually ascending posterior margin of Batola n. gen. is unique within Blattulidae.

\section{DESCRIPTION}

Head large, hypognathous, with occipital area with characteristic two stripes. First and third antennal segments very long. Maxillary palp short and robust, with apical three segments of subequal length, apical segment with dense very slender chaetae.

Pronotum extremely short and wide, with sophisticated coloration. Body wide, cerci short, robust, with very long sensilla chaetica.

Forewings with ascending posterior margin and sharply curved posterior basis. Hindwing protruding beyond the forewings.

Sc simple; $\mathrm{R}$ branches dichotomized only apically; $\mathrm{M}$ simplified to few long branches; $\mathrm{CuA}$ expanded; A simple.

\section{REMARKS}

Batola n. gen. bears no plesiomorphies in respect to Elisama, and Elisama bears no apomorphies in respect to Batola n. gen., the former being thus ancestral for Batola n. gen. Unless homoplastic, the most related taxon within Elisama appears to be E. liaoningensis Hong, 1986 from Northern China (Hong 1986), the sole Elisama species with ascending posterior margin. Nevertheless, according to the unusual large size (forewing length over $12 \mathrm{~mm}$ ) it is perhaps not directly related.

The 3D preservation with hindwings projected beyond forewings resolved the obscurity of the darkening of hindwing apex in many unrelated taxa (Blattulidae, Caloblattinidae, Raphidiomimidae, Skokidae) and its protective function.

\section{Batola nikolai $\mathrm{n} . \mathrm{sp}$. \\ (Figs 1; 2; 8-12; 16B, E, G, H)}

TYPE MATERIAL. - Holotype: ARC-254.4, complete immature feeding on a strobillus. Paratypes: ARC-261.1, adult male wings with body, terminalia and legs; ARC-037b, a complete (4th) immature; ARC-128, body of male (?2nd) immature; ARC-138, a hind leg of a subadult or adult; ARC47, a complete (?1st) immature; ARC-57.2, a hind leg.

TYPe LOCALITY. - Archingeay-Les Nouillers, CharenteMaritime, SW France.

STRATIGRAPHIC HORIZON. - Lower Cretaceous, uppermost Albian, lithological subunit A1s12 sensu Néraudeau et al. (2002).

Etymology. - After my son Nikolaj.

\section{DESCRIPTION}

Adult male, ARC-261.1 (Figs 2; 10)

Pronotum, even when unpreserved, and position of wings apparently very wide. Forewings wide $(6.8 / 2.4 \mathrm{~mm})$; the right forewing overlaps the left one. Coloration generally expanded, particularly in the whole posterior margin of the wing. Sc simple, curved dorsally. R with 9(L)-11(R) mostly simple branches, only apicalmost branches dichotomizing; $\mathrm{M}$ reduced to 2(L)-4(R) branches. CuA expanded, with 5(R)-7(L) branches, with the space for additional basalmost branch free. CuP sharply curved, five or six anal veins simple.

Hindwing concealed under forewings except for apex.

Hind legs long, coxa terminated with two series of rectangular setae (Fig. 2D), femur robust 
$(2.4 / 0.8 \mathrm{~mm})$ with two strong supporting ridges and with three median setae. Posterior margin with two ridges bearing $5+7$ setae. Dorsal terminal spur comparatively short, posterior margin with short chaeta and long terminal spur; tibia $3.2 \mathrm{~mm}$ long with slender long spurs and long strong terminal spurs, all in four rows, and with numerous very short chaeta. Base of hind leg segments round in section, with ridge present only shortly at base. Dark coloration present in basal, median and apical parts of tibiae. Subgenital plate with margins plain, with styli multisegmented (eight or more), c. $0.8 \mathrm{~mm}$ long. Cerci wide, of standard appearance.

Complete (?second) immature feeding on strobillus, ARC-254.4 (Figs 1; 11)

Very robust individual. Head almost as wide $(1.1 \mathrm{~mm})$ as pronotum. Antenna of standard appearance, with at least 22 segments, width c. $0.04 \mathrm{~mm}$. Three basal segments very long $(0.67 \mathrm{~mm})$, pedicel short. Each segment bearing a set of transversal ridges and five to seven subapical sensilla chaetica about as long as half segment length. Starting with the 9th segment, setae forming two rows. Segments dark basally. Maxillary palps short and thick, three terminal segments visible $(0.18 / 0.2 / 0.22 \mathrm{~mm})$.

Pro-, meso- and metanotum with apparent long marginal setae (dark coloration as in Figures 1 and 11). Pronotum very wide, strongly transversal $(0.6 / 1.2 \mathrm{~mm})$. Body wide $(1.6 \mathrm{~mm})$ and coloured, six undifferentiated terga visible, supragenital plate terminated with six sensilla chaetica. Cerci long and massive, with seven visible segments and long sensilla chaetica. Each segment bears a set of two strong sensilla chaeta and 2-6 extremely long sensilla chaetica.

Legs short, carinated. Fore coxae comparatively long $(0.69 \mathrm{~mm})$, trochanter distinct $(0.25 \mathrm{~mm})$, femur robust $(0.84 / 0.2 \mathrm{~mm})$, tibia short and thin (0.6/0.1 mm), tarsus very long (0.77 mm: 0.24/0.22/ $0.11 / 0.07 / 0.13 \mathrm{~mm})$. Mid coxa shorter $(0.33 \mathrm{~mm})$, less distinct than the fore coxa; trochanter very large $(0.33 \mathrm{~mm})$ femur robust $(0.8 / 0.27 \mathrm{~mm})$; tibia arcuate near basis, $0.69 \mathrm{~mm}$ long, with numerous spurs and chaeta; tarsus very long $(0.71 \mathrm{~mm}$ : $0.27 / 0.16 / 0.12 / 0.05 / 0.11 \mathrm{~mm}$ ) with $8-10$ rows of

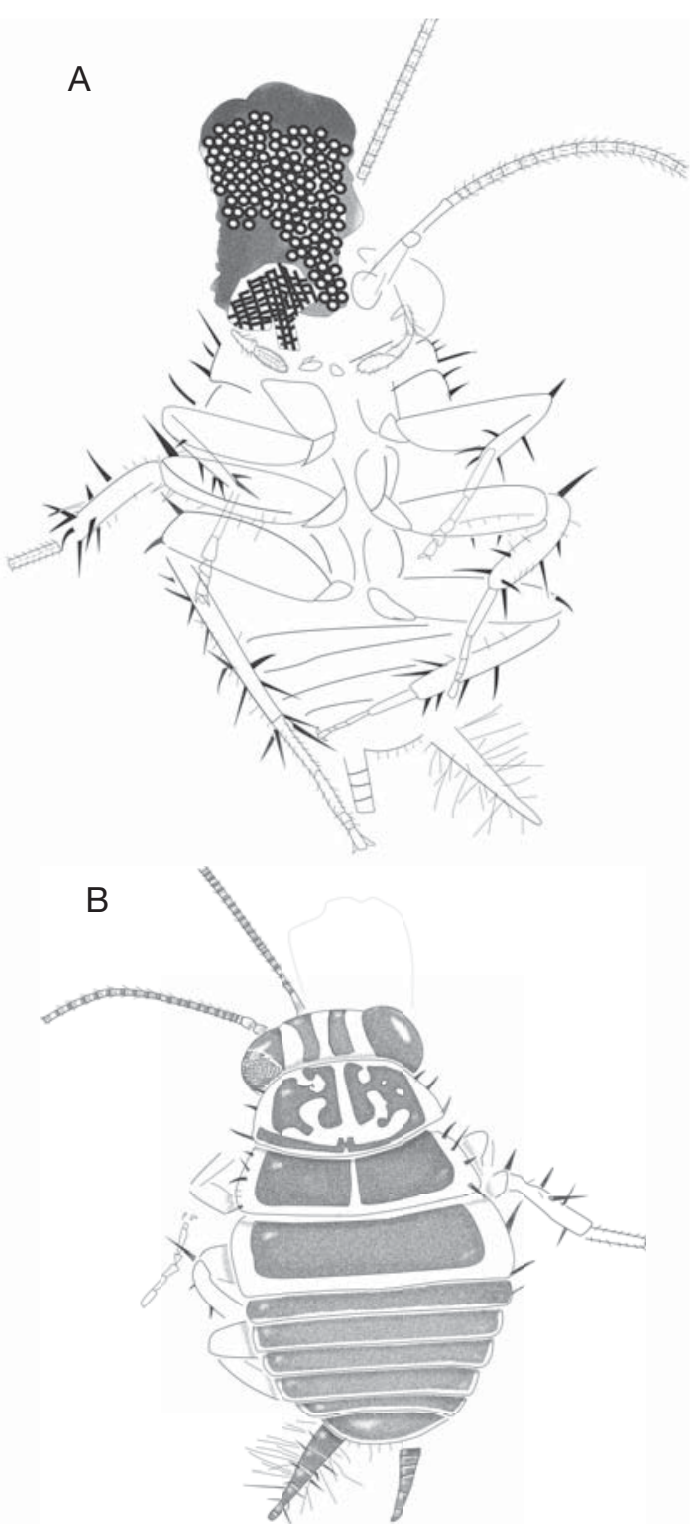

FIG. 1. - An immature of Batola nikolai n. gen., n. sp. (Blattulidae) feeding on strobilus, holotype ARC-254.4: A, general habitus in ventral view; B, dorsal view. Length of the specimen $2.7 \mathrm{~mm}$.

chaeta. Hind coxa large $(0.36 \mathrm{~mm})$, trochanter very large $(0.33 \mathrm{~mm})$; femur robust $(0.93 / 0.31 \mathrm{~mm})$ with short terminal spur; tibia long and thin $(1.09 / 0.1 \mathrm{~mm})$, with numerous spurs and chaeta. Tarsus long $(0.85 \mathrm{~mm})$ with numerous chaeta 
(0.36/0.24/0.07/0.05/0.13 mm). Overall specimen length $c .2 .7 \mathrm{~mm}$.

\section{Complete (?fourth) immature, ARC-037b1}

(Figs 8-10)

Very robust individual, but body comparatively not as wide as in the preceding immature. Head comparatively smaller $(1.26 / 1.47 \mathrm{~mm})$ in respect to pronotum $(1.4 / 2.3 \mathrm{~mm})$. Eyes long and narrow, not protruding beyond the head outline. Maxillary palps comparatively slender and narrow, terminal three segments $0.63 / 0.47 / 0.63 \mathrm{~mm}$ long.

Mesonotum wider than pronotum $(2.73 \mathrm{~mm})$, metanotum slightly narrower $(2.67 \mathrm{~mm})$. Body $2.5 \mathrm{~mm}$ wide. Cercus length $c .1 .27 \mathrm{~mm}$.

Leg carination very strong. Fore coxae $(1.05 \mathrm{~mm})$ and femora $(1.26 \mathrm{~mm})$ extremely long, tibia short $(1.05 \mathrm{~mm})$, tarsi long $(0.58 / 0.21 /$ $0.16 / 0.05 / 0.42 \mathrm{~mm})$. Mid femur very robust $(1.58 / 0.47 \mathrm{~mm})$, tibia short $(1.32 \mathrm{~mm})$, tarsi long $(0.63 / 0.26 / 0.11 / 0.11 / 0.37 \mathrm{~mm})$. Hind femora long and robust $(1.79 / 0.53 \mathrm{~mm})$, tibia long $(1.95 \mathrm{~mm})$, tarsi very long $(0.84 / 0.26 / 0.16 / 0.16 / 0.37 \mathrm{~mm})$. Overall specimen length $c .5 .6 \mathrm{~mm}$.

\section{Detached abdominal apex of male (?second) immature, ARC-128 (Fig. 16B)}

Very robust (width $1.88 \mathrm{~mm})$. Cerci long $(1.27 \mathrm{~mm})$, 8-segmented, each segment with a basal row of 5-7 very long $(0.41 \mathrm{~mm})$ sensilla chaetica, median row of 3 or 4 short sensilla chaetica and apical row of 5-9 short sensilla chaetica; short styli with numerous sensilla chaetica present. Apical (8th) sternum significantly prolonged medially, forming a protective sheath.

\section{$A$ hind leg of a subadult or adult, ARC-138R (Fig. 16E)}

Melted and damaged specimen, femoral length $1.8 \mathrm{~mm}$.

Complete (?first) immature, ARC-47 (examined on a low-quality photograph)

Head very large, globular, $c .1 .07 \mathrm{~mm}$ wide. Pronotum very short $(0.43 / 0.95 \mathrm{~mm})$. Body width $1.19 \mathrm{~mm}$. Hind tibia $0.90 \mathrm{~mm}$ long. Overall length of the individual c. $2.3 \mathrm{~mm}$. Coloration characteristic of Batola n. gen.
Hind leg, ARC-57.2 (Fig. 16G, H)

Coloration not preserved. Coxa short $(0.34 \mathrm{~mm})$, without reticulations. Femur almost round in section (length/width 1.65/0.45 mm), fore and hind margins with numerous long chaeta. Terminal spur short. Ventral anterior side with a set of numerous (c. 20) sensilla chaetica, cumulated basally, posterior side with two parallel rows of very small spines. Tibia $(1.65 / 0.23 \mathrm{~mm})$ heavily carinated; with section round at base, elongate apically, with basal part of the posterior margin lacking spurs. Spur length c. $0.31 \mathrm{~mm}$. Numerous sensilla chaetica present in both anterior and posterior sides. First tarsal segment $(0.73 \mathrm{~mm})$ with two sets of two rows of 10 sensilla chaetica and with very strong central longitudinal elevation, with a pair of rows of 10 sensilla chaetica; second segment $(0.19 \mathrm{~mm})$ with four sensilla chaetica in each row; third segment $(0.10 \mathrm{~mm})$ with two sensilla chaetica in each row.

\section{REMARKS}

All specimens may be included within the present taxon based on the similar habitus with unusually short and wide pronotum, and thus also wide position of forewing bases, legs basing on metrics. The standard Cretaceous assemblages consist of two related sister species of Blattulidae and the same appears to be present here.

The expanded forewing coloration is an autapomorphy, inherited from Elisama, apparent ancestor of Batola n. gen.

Surprisingly, other modified structures of Batola nikolai n. sp. are palps more slender compared to Elisama. Such palps are known also from the Hauterivian amber Blattulidae from Lebanon (Anisyutkin \& Gorochov 2008). Reason for the presence of shorter palps in amber, and thus in forest dweller, is unknown. Possible explanation can be the collection of pollen as evidenced by the preservation state of the type.

Basing on three specimens of different immatures, the reconstruction of number of instars can be made for Batola nikolai n. sp. The specimen ARC-47 with the overall length $2.3 \mathrm{~mm}$ most likely represents the first instar, even when specimen ARC-254.4, with the overall length $2.7 \mathrm{~mm}$ most likely represents the second instar (see also 


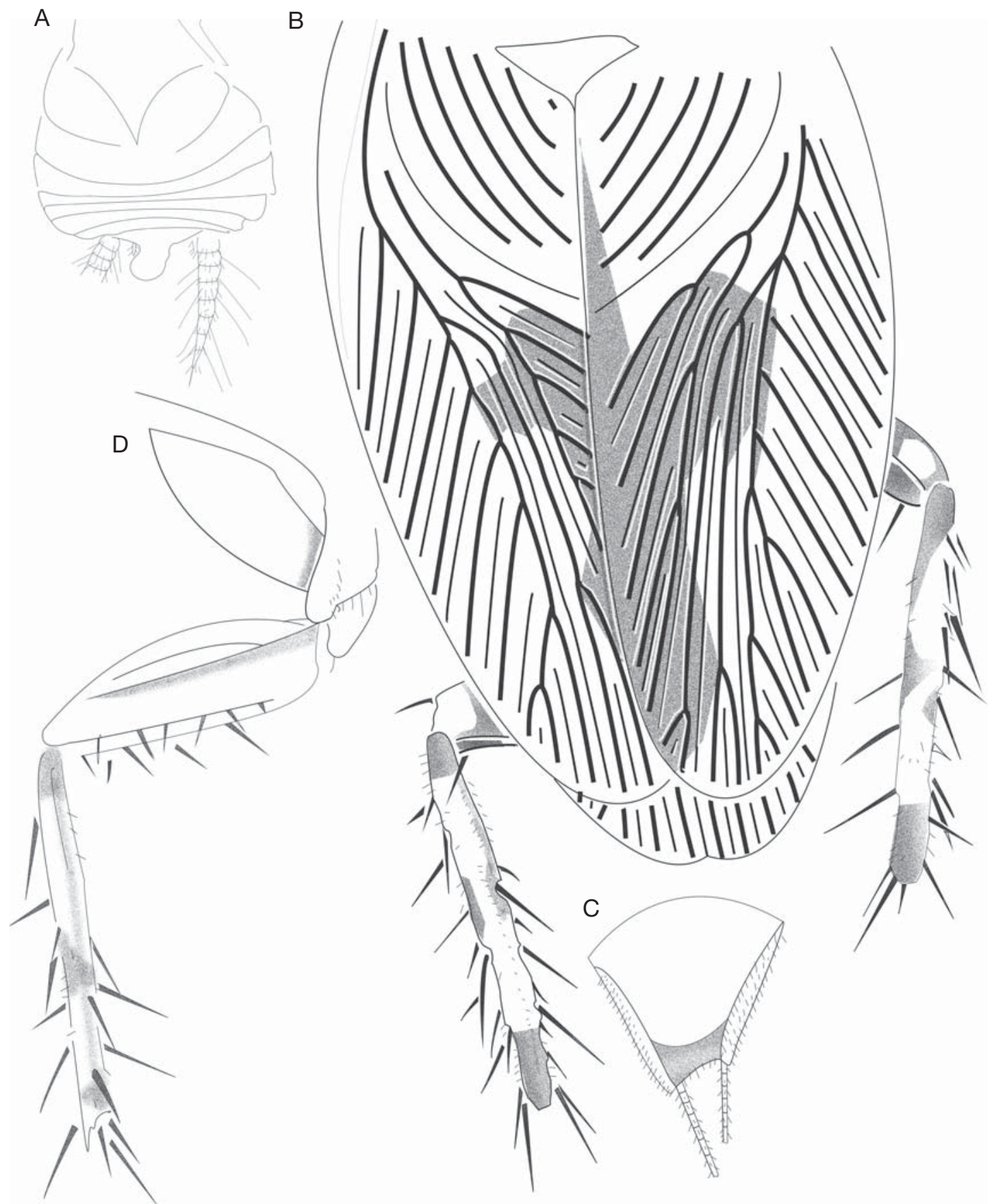

FIG. 2. - Adult male of Batola nikolai n. gen., n. sp. (Blattulidae): A, specimen ARC-128 body and terminalia of male (body width $1.88 \mathrm{~mm}$ ); B, specimen ARC-261 (length of the wing $6.8 \mathrm{~mm}$ ), general habitus; C, same, detail of terminala; $\mathbf{D}$, same, ventral view of the right hind leg. 


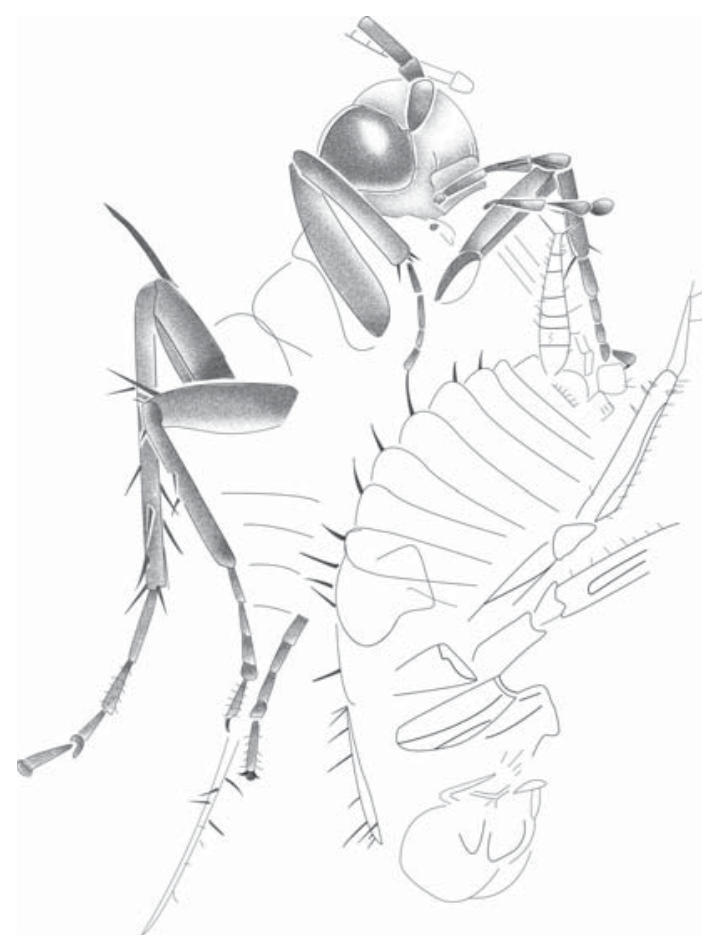

FIG. 3. - Immature of Globula lake n. gen., n. sp. (left), holotype ARC-309.2, and specimen of uncertain family. Distance between apexes of two heads $3.2 \mathrm{~mm}$.

Vršanský 2008a). Applying the Dyar's rule of succeeding instars sizes multiplied by 1.4 validated for Mesozoic cockroaches (Vršanský 1997), the first instar should be only c. $1.9 \mathrm{~mm}$ long, a size comparable to first immature stages of certain Blattulidae (unpublished) (as well as the size of the specimen ARC-47). Consequently, the third instar can be expected to be 3.5-3.8 mm long, the fourth 4.9-5.3 $\mathrm{mm}$ - a size comparable to the specimen no. ARC-037b; the fifth 6.9-7.4 (7.8 mm), which has a size comparable to the present adult.

The size distribution provides a strong support for a small number of instars of the Blattulidae (4-5 plus imago), analogically as in some small living cockroaches.

The nymph was apparently feeding on microstrobilus, fallen into the amber. Decaying organic piece perhaps attracted attention of cockroach, which has been buried during the consumption.
The wide body habitus of the present species is very unusual within the family, and rare in the Mesozoic imprint cockroaches in general. Nevertheless, it appears logical according to the hypothesis of the amber representing fallen drops of resin on the ground, as suggested by Perrichot (2004) and then having trapped mostly ground dwellers. This is evidenced here by melting traces being horizontal, rectangular in respect to the specimen orientation instead of longitudinal. This hypothesis appears supported also by the reduction of the pronotum in two unrelated species, allowing the free movements of head and dorsal view, necessary for detection and avoidance of larger predators. Opposite evidence is provided by free-living cockroaches such as Ectobius Stephens, 1835, which retain wide pronotum.

The dominance of the Blattulidae is not surprising as they represent the most mass insects among small cockroaches (the smallest among the mass cockroaches).

\section{Genus Globula n. gen.}

ETYMOLOGY. - After globus (Latin for globe) - alluding to the large globular head.

DiAgNOSIs. - Head extremely large, globular. Apical femoral spur extremely long and sharply curved. Coxa with reticulations (Fig. 7C).

\section{DESCRIPTION}

Head large, globular, with eyes projected beyond the head outline. Antenna very long (1.5 times longer than the total body length), with long sensilla chaetica in several rows. Palps of short-type (characteristic of the Blattulidae), but unusually long, with the third segment curved. Legs thin and slender, the hind leg with very robust and long, curved apical spur. Tarsi and cerci extremely long.

\section{REMARKS}

The present taxon is preliminary categorized within Blattulidae based on characteristic antennal sensilla chaetica, large globular head, short and robust palps. Nevertheless, the curved second segment of palps, slender hind legs and extremely long apical femoral spur are characters unknown in any 
Blattulidae, and thus the attribution within some other families (Caloblattinidae or some unknown family) cannot be definitively excluded. Moreover the extremely long slender cercus is uncharacteristic of the Blattulidae. The erection of a new family based on unperfectly preserved nymph appears not supported enough.

If belonging to the Blattullidae, the present taxon is well established basing on the abovementioned differences, and can be related only to the Nula Vršanský, 2008 from the Cenomanian Sisteron amber based on the reticulations of the coxa. On the other hand, Nula is a standard blattulid with a completely different habitus with head of a standard size. The coxa reticulations may be eventually plesiomorphic and characteristic for the Caloblattinidae (structure of coxae are unknown in Caloblattinidae) or some unknown family.

\section{Globula lake n. sp.}

(Figs $3 ; 15 ; 16 \mathrm{D}$ )

TYPe MATERIAL. - Holotype specimen ARC-309.2, a complete immature. Paratypes specimens ARC-60, an immature and ARC-263.14, a hind leg.

Type LOCALITY. - Archingeay-Les Nouillers, CharenteMaritime, SW France.

ETYMOLOGY. - Lake is after Malvina Lak, who provided synchrotron images for this publication.

STRATIGRAPHIC HORIZON. - Lower Cretaceous, uppermost Albian, lithological subunit A1sl 2 sensu Néraudeau et al. (2002).

\section{DESCRIPTION}

\section{ARC-309.2, a complete immature}

Head height $0.7 \mathrm{~mm}$, antenna width $0.04 \mathrm{~mm}$.

Maxillary palps (three apical segments: 0.18/0.17/

$0.14 \mathrm{~mm}$ ), the two terminal segments with two distinct longitudinal dorsal ridges, terminal segment with 8 apical short, slender sensilla chaetica.

Fore femur long and narrow $(0.70 / 0.18 \mathrm{~mm})$, tibia also long $(0.54 / 0.08 \mathrm{~mm})$, tarsus very long $(0.17 / 0.08 / 0.11 / 0.06 / 0.16 \mathrm{~mm})$. Mid femur robust $(0.56 / 0.19 \mathrm{~mm})$, tibia short $(0.71 \mathrm{~mm})$, tarsus long $(0.13 / 0.12 / 0.13 / 0.06 / 0.19 \mathrm{~mm})$. Hind femur slender $(0.79 / 0.18 \mathrm{~mm})$, with massive long terminal spur $(0.43 \mathrm{~mm})$, tibia very long $(1.18 / 0.06 \mathrm{~mm})$, tarsus very long $(0.30 / 0.21 / 0.15 / 0.09 / 0.22 \mathrm{~mm})$.

\section{ARC-263.14, hind leg}

Coxa very short, but unusually wide, dark, with characteristically reticulated surface. Other parts of the extremity pale (without coloration). Femur almost round in section, comparatively long and narrow $(1.21 / 0.35 \mathrm{~mm})$, with extremely long terminal spur $(0.49 \mathrm{~mm})$. Some of tibial spurs are also unusually long $(0.50 \mathrm{~mm})$. Tibia medium-sized, $1.7 \mathrm{~mm}$ long. Both femoral and tibial sensilla chaetica are sparse, tarsus $(0.91 \mathrm{~mm})$ dark, with numerous sensilla chaetica.

\section{ARC-60}

Very early instar, with metanotum width $0.95 \mathrm{~mm}$; body width $0.88 \mathrm{~mm}$; and cercus length $0.49 \mathrm{~mm}$.

\section{REMARKS}

Specimens ARC-263.14 and ARC-60 can be categorized as belonging to the present taxon based on the very long hind femoral apical spur.

\section{Superfamily CALOBLATTINOIDEA Vršanský \& Ansorge, 2000 \\ Family CALOBLATTINIDAE Vršanský \& Ansorge, 2000}

DiAGNOSIS. - Very large species (forewing usually well over $15 \mathrm{~mm}$, extremely rarely $10-12 \mathrm{~mm}$ ). Maxillary palp long. Body plain, cerci with numerous segments without long sensilla chaetica; multisegmented styli present. Female with very long external ovipositor. Wings with round veins $(+)$ and also round intercalaries (-), usually without cross-veins. Sc branched; RS differentiated; A branched. Hindwing with differentiated RS, usually with tertiary branched $\mathrm{CuA}$, simple $\mathrm{CuP}$ and straight A1. Pleating is veer-like.

\section{Genus and species indet.}

(Figs 7; 16D)

MATERIAL. - Holotype specimen ARC-152.3, pyritized mid and hind legs.

LOCALITY. - Archingeay-Les Nouillers, CharenteMaritime, SW France. 
STRATIGRAPHIC HORIZON. - Lower Cretaceous, uppermost Albian, lithological subunit A1sl 2 sensu Néraudeau et al. (2002).

\section{DESCRIPTION}

Anterior margins of both femora with numerous spurs and sensilla chaetica, terminal spur thick but rather short. Both femora with two parallel longitudinal ventral ridges. Both tibiae carinated, spurs strong but short. Mid tibia short $(1.35 / 0.27 \mathrm{~mm})$, hind tibia long $(2.25 / 0.29 \mathrm{~mm})$. Tarsi long $(0.95 / 0.27 / 0.22 / 0.16 / 0.27 \mathrm{~mm})$, the first tarsal segment with longitudinal medial elevation.

\section{REMARKS}

The present specimen can be categorized within Caloblattinidae based on large size (only families Caloblattinidae, Latiblattidae and Raphidiomimidae have species with such large individuals), short legs are uncharacteristic for the Raphidiomimidae; Latiblattidae on the other hand do not have slender legs. An alternative would be a new, unknown family, which seems unlikely as Caloblattinidae were the dominant Mesozoic family.

The latest described representatives of the family Caloblattinidae (Barremian of Mongolia) are distant in time for more than $20 \mathrm{Ma}$, and thus the present specimen most likely represents a separate genus and species. Nevertheless, it would be too risky to describe the present taxon based on legs only.

The coloration of the specimen has been lost due to the pyritization.

\section{Family EADIIDAE n. fam.}

\section{Type Genus. - Eadia n. gen.}

OTHER GENUS INCLUDED. — ? Raphidiomimula Grimaldi \& Ross, 2004 from the Upper Albian Burmese amber.

RANGE. - Eurasia, Upper Albian.

DifFERENTIAL DIAGNOSIS. - The family may be included within Dictyoptera based on the general habitus, hypognathous head, multisegmented, partially fusiform cerci and wing pads. It can be further categorized as belonging to cockroaches and not to mantises based on the generally short body, short pronotum and particularly cursorial forelegs with short tibiae (but with two rows of spurs like in mantises and liberiblattinid cockroaches), and extremely long tarsi.

Eadiidae n. fam. differs from all known cockroach families in having hypognathous, but largely expanded and prolonged head, extremely short pronotum, by curved carination and long tarsi of forelegs and by extremely elongated cerci.

\section{DESCRIPTION}

Head hypognathous, largely prolonged. Eyes (with small facets) protruding beyond the head outline. Three ocelli present. Pronotum extremely short and wide. Wing pads distinct. Legs robust, forelegs tibiae short, with sharply curved spurs, fore tarsi extremely long. Cercus extremely long, and in the apical half extremely narrow.

\section{REMARKS}

The extremely long extremities, and long narrow maxillary palps resembling those of families Caloblattinidae and Raphidiomimidae (symplesiomorphies), exclude affinities with Polyphagoidea (including Liberiblattinidae and Skokidae), Umenocoleoidea and Blattuloidea. The generally short body and elongated fore tarsi are strong autapomorphies, the former eventually serving for capturing prey. Another possible synapomorphy with primitive mantises is the elongated cercus.

The composition of head is a strong autapomorphy, a trend towards prolongation perhaps inherited from the Caloblattinidae, whose heads are diverse. Raphidiomimidae have prognathous head (autapomorphy) and very short fore tarsi (plesiomorphy). Thus, the new family may be attributed within Caloblattinoidea and derived directly from the Caloblattinidae.

Even when the morphology of head appears identical with the Raphidiomimula, the categorization of this genus is obscure, because of its longer pronotum and shorter tarsi.

\section{Genus Eadia n. gen.}

TyPE SPECIES. - Eadia aidae n. sp., by monotypy.

Differential diagnosis. - Head like in Raphidiomimula Grimaldi \& Ross, 2004 (whith temporal space invisible, and thus the presence of ocelli not validated). Whole body considerably shorter, and robust, cerci more 
derived, elongated with narrow, almost filiform distal half. Fore tarsi considerably longer.

Etymology. - After eàdem, Latin for "by the same way".

\section{DESCRIPTION}

Eyes large, protruding beyond the head outline. Facets very small. Space between eyes very wide. Three ocelli are plain and pale, covered by cuticle. Three rows, each with 10 short chaeta, present above clypeal sutura. Maxillary palp long and narrow, with sparse slender sensilla chaetica. Fore femur with two distinct rows of spurs, tibia with very strong, curved spurs. Tarsi very long (longer than tibiae), with numerous small sensilla chaetica. Cerci long, of standard general fusiform habitus in basal half, but extremely thin and elongated apically.

\section{REMARKS}

The robust and considerably shorter body, and even more elongated cerci are strong autapomorphies.

\section{Eadia aidae n. sp.}

(Figs 4; 14)

TYPe MATerial. - Holotype specimen ARC-263.16, complete immature.

TYPe LOCALITY. - Archingeay-Les Nouillers, CharenteMaritime, SW France.

STRATIGRAPHIC HORIZON. - Lower Cretaceous, uppermost Albian, lithological subunit A1s12 sensu Néraudeau et al. (2002).

Etymology. - After Aida. Eadia aidae is a palindrome.

\section{DESCRIPTION}

Head very long and wide $(1.96 / 1.90 \mathrm{~mm})$. Facets very small; ocelli comparatively large (diameter $0.15 \mathrm{~mm}$ ). Maxillary palp long and thin, apical segments of subequal length $(0,33 / 0.36 / 0.39 \mathrm{~mm})$. Three rows each with about 10 sensilla chaetica present at frons. Pronotum extremely short $(0.47 / 1.96 \mathrm{~mm})$; mesonotum with wing pads $(0.74$ [central part] $/ 2.67 \mathrm{~mm})$; metanotum (0.89 [central part]/2.97 $\mathrm{mm})$.

Fore femora robust $(1.28 / 0.5 \mathrm{~mm})$ with two rows of four spurs each; fore tibia thin $(1.19 / 0.15 \mathrm{~mm})$ with numerous thick and strongly curved spurs; fore tarsi very long $(0.42 / 0.36 / 0.21 / 0.19 / 0.36 \mathrm{~mm})$, with dense sensilla chaetica in 10 rows (segment 4 with $4 \times 10$ sensilla chaetica). Mid femora robust and wide (width $0.5 \mathrm{~mm}$ ), with strong terminal spur (12-14 helical ridges); mid tibia quite robust $(1.75 / 0.24 \mathrm{~mm})$ strongly carinated. Hind legs very long, with tibia thin $(2.73 / 0.24 \mathrm{~mm})$, carinated. Cercus very long $(2.14 / 0.24 \mathrm{~mm})$.

\section{REMARKS}

Free head with huge number of small eye facets indicate diurnal habits, supported by the reduced length of pronotum, enabling movable head. Elongated fore tarsi with numerous very large sensilla indicate strong sensorial function of legs, similar to earliest mantises. Nevertheless, its functional morphology remains obscure.

\section{Superfamily PolyPHAGOIDEA Walker, 1868}

\section{Family LiBERIBLATTINIDAE Vršanský, 2002}

DiAGNOSIS. - Head globular, eyes projected more or less within outline of the head. Antennal segments bearing median short sensilla chaetica. Maxillary palp robust. Body thick, cerci with few segments. Female with internalised or short external ovipositor. Wings with round dark veins and more pale round intercalaries, usually strongly curved (also locally, with local irregularities), with cross-veins. Sc very long, branched; RS not differentiated; A simple or branched. Hindwing with simply branched R1, differentiated RS, with secondarily branched $\mathrm{CuA}$, simple $\mathrm{CuP}$ and curved and branched A1. Pleating not veer-like.

\section{Genus Leptolythica n. gen.}

TYPE SPECIES. - Leptolythica vincenti n. sp., by monotypy.

ETyMology. - Combination of leptos (Greek for small) and lythos (Greek for stone), as a dedication to my colleague and friend Vincent Perrichot whose family name means "small stone" in the language of his native region the Brittany.

DifFERENTIAL DIAGNOSIS. - The present taxon may be categorized as Liberiblattinidae based on almost ideally globular head, robust antenna and foreleg with two parallel rows of spines along the tibial posterior ridge. 


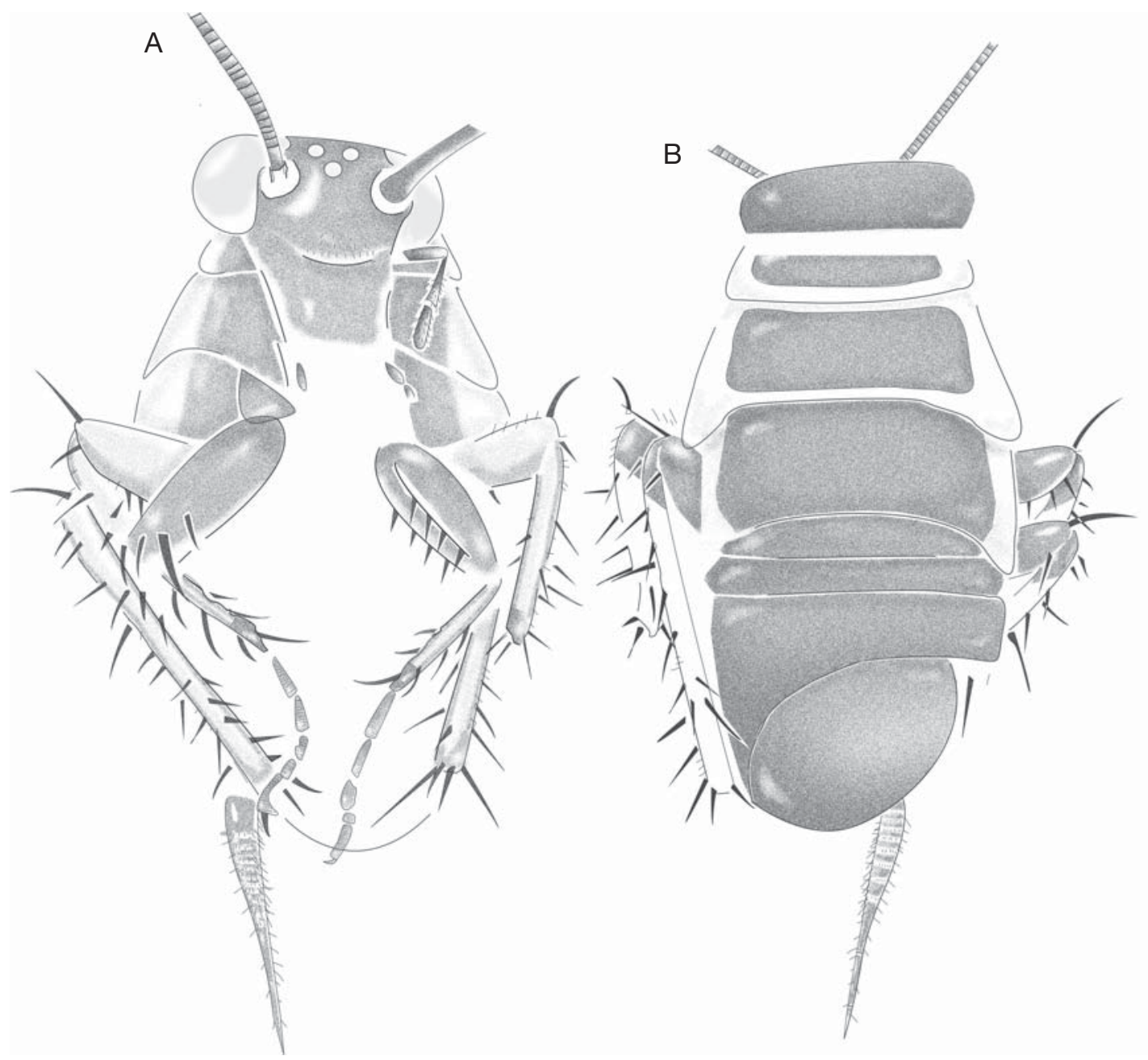

FIG. 4. - An immature of Eadia aidae n. gen., n. sp. (Eadiidae n. fam.), holotype ARC-263.16: A, ventral view; B, dorsal view. Head width $1.9 \mathrm{~mm}$.

Leptolythica n. gen. differs from all other genera in having extremely short maxillary palps (autapomorphy).

According to the rapid evolutionary tempo of early Liberiblattinidae, and despite the absence of diagnostic wings, the presence of one and the same genus in localities distant in time for at least $45 \mathrm{Ma}$ (the latest published record of the Liberiblattinidae is Elisamoides Vršanský, 2004 from the Tithonian of Shar-Teg in Mongolia) is very unlikely. Thus we safely erect a new genus to include the present species.

\section{DESCRIPTION}

Head globular, with comparatively large, round eyes. Scape and pedicel very large as well as the third antennal segment; fourth segment very short. Antenna very short, with subequal, short and wide segments. Clypeus distinct. Mandibles slender, comparatively small. Labial palps distinct, coloured, with slender dense sensilla chaetica. Maxillary palp robust, thick but short, without coloration, with few sensilla chaetica. Apical segment the largest.

Forelegs cursorial, with two rows of slender spurs along longitudinal posterior femoral ridge and a strong terminal spine. Few short sensilla chaetica present on the anterior margin. Tibia short, with strong spurs. Tarsi very short and robust, with 
dense sensilla chaetica. Mid legs with comparatively short coxa, well-developed trochanter and robust femur and tibia. Femur with long sensilla chaetica on posterior, and short ones on anterior margins. Two longitudinal median ridges present. Tibia with strong spurs.

\section{REMARKS}

Robust foreleg tibia with massive tarsi and robust maxillary palps are unique autapomorphies, eventually linked with the life within forest litter and/ or, possibly, for digging.

Due to the absence of diagnostic wings, no relationships can be established. The general habitus indicates relationship with the Late Jurassic undescribed small Liberiblattinidae from the Karabastau Formation (unpublished).

\section{Leptolythica vincenti $\mathrm{n}$. sp.}

(Figs 5; 13)

Type MATERIAL. - Holotype specimen ARC-260.2, a complete immature.

Type LOCALITY. - Archingeay-Les Nouillers, CharenteMaritime, SW France.

STRATIGRAPHIC HORIZON. - Lower Cretaceous, uppermost Albian, lithological subunit A1sl2 sensu Néraudeau et al. (2002).

Eтyмоlogy. - After my colleague and friend Vincent Perrichot.

\section{DESCRIPTION}

Head globular, $1.14 \mathrm{~mm}$ wide, eyes globular, comparatively small. Clypeus distinct $(0.46 / 0.16 \mathrm{~mm})$. Antenna very short, with only 37 segments, each with 1 (basal)-3 (apical segments) rows of 2-4 comparatively short sensilla chaetica. Scape $0.29 \mathrm{~mm}$, pedicel $0.16 \mathrm{~mm}$ long. Third antennal segment the longest $(0.31 \mathrm{~mm})$, fourth the shortest $(0.05 \mathrm{~mm})$. All segments (except scape $0.15 \mathrm{~mm}$ at apex) very wide $(0.1 \mathrm{~mm})$.

Labial palp slender, long $(0.31 / 0.07 \mathrm{~mm})$, with dense sensilla chaetica, very dense at apex (10 apical sensilla chaetica on dorsal side). Maxillary palp transparent, with distinct articulation, first segment short $(0.22 / 0.09 \mathrm{~mm})$, second distinct $(0.73 / 0.35 \mathrm{~mm})$,

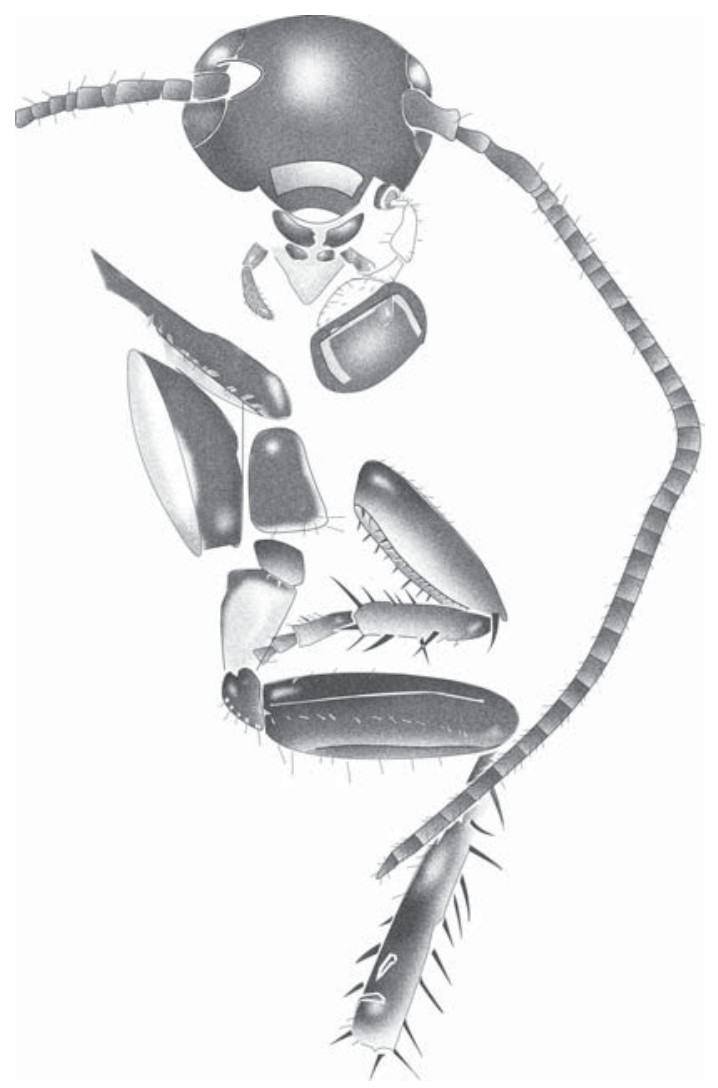

FIG. 5. - An immature of Leptolythica vincenti n. gen., n. sp. (Liberiblattinidae), holotype ARC-260.2, ventral view of complete specimen. Head width $1.14 \mathrm{~mm}$.

third reduced to some extent $(0.55 / 0.35 \mathrm{~mm})$, the apical one very large $(1.00 / 0.42 \mathrm{~mm})$, with sparse sensilla chaetica.

Fore femur robust, short $(0.85 / 0.29 \mathrm{~mm})$ with two rows of 17 and 9 spurs along longitudinal posterior ridge, with large terminal spine. Tibia very short and robust $(0.57 / 0.14 \mathrm{~mm})$, strongly carinated, but with few sensilla chaetica. Tarsus robust, basitarsus $(0.25 / 0.09 \mathrm{~mm})$ with at least 5 apical sensilla chaetica and a longitudinal ridge, second $(0.11 / 0.07 \mathrm{~mm})$ and third $(0.10 / 0.07 \mathrm{~mm})$ segments without sensilla chaetica. Mid coxa comparatively short $(0.48 \mathrm{~mm})$, trochanter very distinct $(0.33 \mathrm{~mm})$, femur $(1.21 / 0.4 \mathrm{~mm})$ with two longitudinal central ridges, posterior margin with 8 , anterior with 4 sensilla chaetica of diverse length. 
Mid tibia very long $(1.61 / 0.22 \mathrm{~mm})$, strongly carinated.

\section{Superfamily BLATTOIDEA Latreille, 1810}

\section{Family MesoblatTINIDAE Handlirsch, 1906}

Diagnosis. - Head globular, eyes projected more above the outline of the head. Antennal segments with few very short subapical sensilla chaetica. Maxillary palp of mediate length. Body plain, cerci with about 15 segments without long sensilla chaetica; styli absent. Female with internalized, sometimes reduced external ovipositor. Wings with round dark veins and pale round intercalaries. Sc simple or with max. 3 branches; RS differentiated; A branched. Hindwing with sophisticated, comb-like R1, differentiated RS; simple $\mathrm{M}$; branched $\mathrm{CuA}$, simple $\mathrm{CuP}$ and simple A1. Pleating veer-like.

\section{Genus Sivis n. gen.}

TYPE SPECIES. - Sivis odpo n. sp., by monotypy.

Etymology. - After si viss (Latin for "if you like it").

DifFERENTIAL DIAGNOSIS. - The present taxon may be categorized within the Mesoblattinidae based on modern morphology of head with globular eyes and clypeus, with strong antenna bearing a row of short sensilla chaetica, by the derived form of pronotum and long marginal chaeta on head, nota and abdomen.

The present genus may be differentiated from Praeblattella Vršanský, 2003 based on the characteristic pronotum coloration, which is sophisticated in Praeblattella.

Mesoblattina, Archimesoblatta Vršanský, 2003 and Hispanoblatta Martínez-Delclós, 1993 differ by having a simpler form of pronotum (plesiomorphy).

The derived form of pronotum is synapomorphic with the Praeblattella, autapomorphic in sophisticated pronotal coloration. The pronotum of Hispanoblatta, Mesoblattina and Archimesoblatta Vršanský, 2003 is plesiomorphic. Brachymesoblatta Vršanský, 2003 belongs to the Liberiblattinae. Thus, Sivis n. gen. may be the sister genus of Praeblattella.

\section{DESCRIPTION}

Head, notum and abdomen with distinct very long marginal sensilla chaetica. Head large, with dark globular eyes protruding beyond the head outline. Antenna very wide, with long scape, shorter pedicel and very long third antennal segment. Mandible very large, with numerous small sharp teeth. Maxillary palp with cup-like apical segment. Pronotum almost quadrate in outline, body not wide.

\section{REMARKS}

Distinct cup-like apical segment of maxillary palp is a phylogenetic novelty, absent in Mesozoic families. The terminal segment may be cup-like in the pollinating Skokidae, but not as distinct as here.

\section{Sivis odpo n. sp. \\ (Figs 6; 8-10; 16C)}

Type Material. - Holotype specimen ARC-89.2, a complete ?2nd instar larva. Paratype specimen ARC037b2, a complete ?2nd instar immature.

TyPe LOCALITY. - Archingeay-Les Nouillers, CharenteMaritime, SW France.

STRATIGRAPHIC HORIZON. - Lower Cretaceous, uppermost Albian, lithological subunit A1sl2 sensu Néraudeau et al. (2002).

Etymology. - After odporučenie (Slavic for recommendation).

\section{DESCRIPTION}

\section{Specimen ARC-89.2 (Fig. 16C)}

Head globular $(0.7 / 0.64 \mathrm{~mm})$, eyes strongly cut around the antennal articulation and projected beyond the head outline. Mandible very long, with at least six small sharp teeth. Antenna long, with segments very wide, third segment the largest $(0.16 / 0.07 \mathrm{~mm})$. Segments $4-7$ with one set of 7 or 8 sensilla chaetica, segments 8 and 9 with two sets, and apical segment with three sets of sensilla chaetica.

Maxillary palp four- or five-segmented (?/0.15/ $0.11 / 0.16 / 0.2 \mathrm{~mm})$, apical segment very wide $(0.13 \mathrm{~mm})$, cup-like.

Pronotum almost quadrate in outline $(0.75 /$ $0.55 \mathrm{~mm})$, meso- and metanotum very wide $(0.86 \mathrm{~mm} ; 0.91 \mathrm{~mm})$. Marginal setae (10 on pro-, meso-, and metanotal posterior margin) very long (up to $0.12 \mathrm{~mm}$ ). Overall length $1.9 \mathrm{~mm}$. 


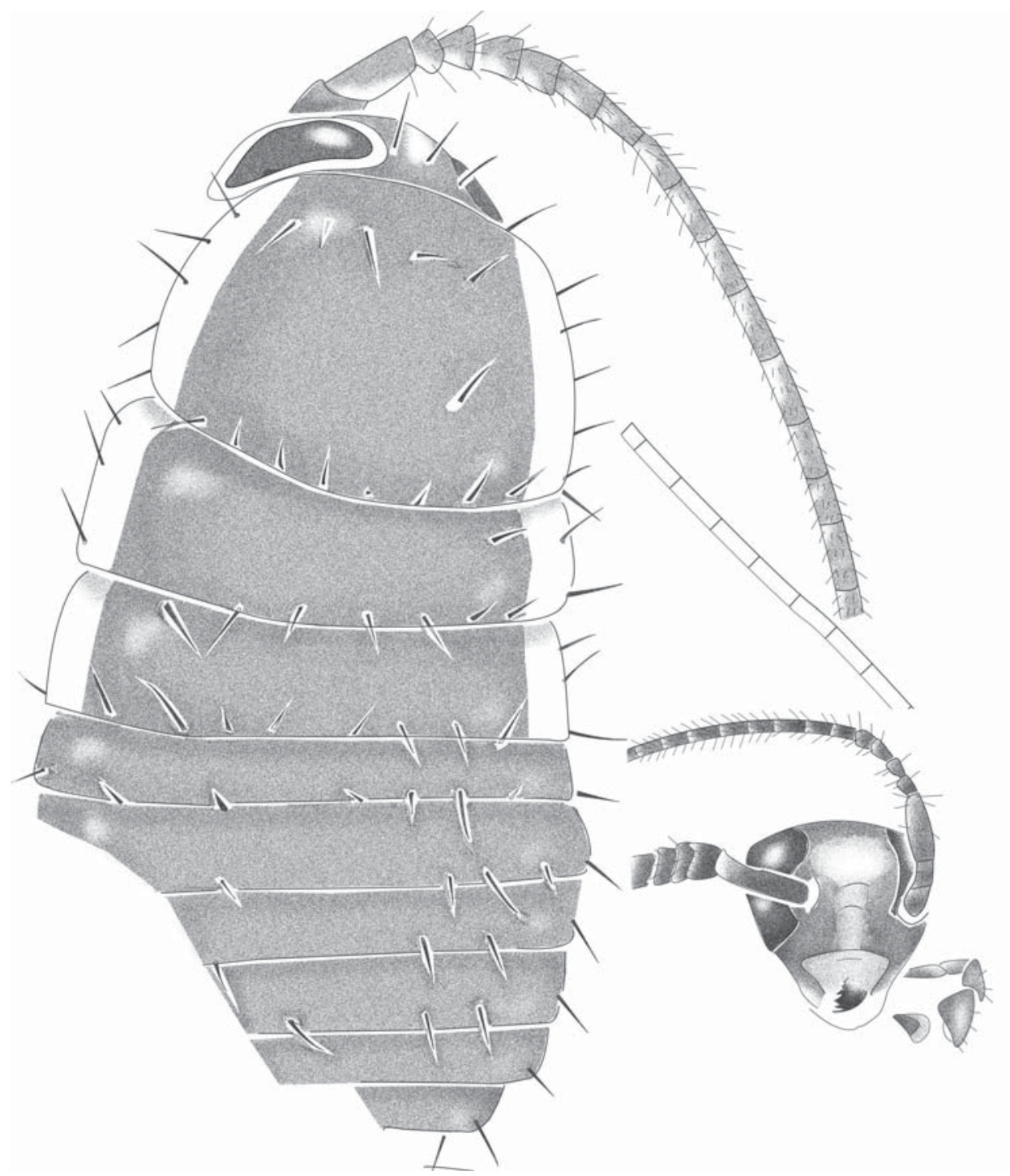

FIG. 6. - An immature of Sivis odpo n. gen., n. sp. (Mesoblattinidae), holotype ARC-89.2: A, general habitus in dorsal view; B, detail of head. Length of the specimen $1.9 \mathrm{~mm}$; head width $0.64 \mathrm{~mm}$.

ARC-037b2 (Figs 7-9)

Head width $0.84 \mathrm{~mm}$; pronotum $(1.05 / 0.68 \mathrm{~mm})$, meso- and metanotum wide $(1.21 \mathrm{~mm}$; $1.32 \mathrm{~mm}$ ). Cercus $0.58 \mathrm{~mm}$ long. Overall length $2.32 \mathrm{~mm}$.

\section{REMARKS}

The holotype is preliminary categorized into the second instar, because the head is projected beyond the pronotum outline only in the first two instars, and the head is partially concealed by pronotum - a state common in the second instar. Specimen ARC-037b2 is an older, apparently the next, third instar. The proportion of the holotype, multiplied by 1.4 (Dyar's rule) roughly fit the above presumption. 


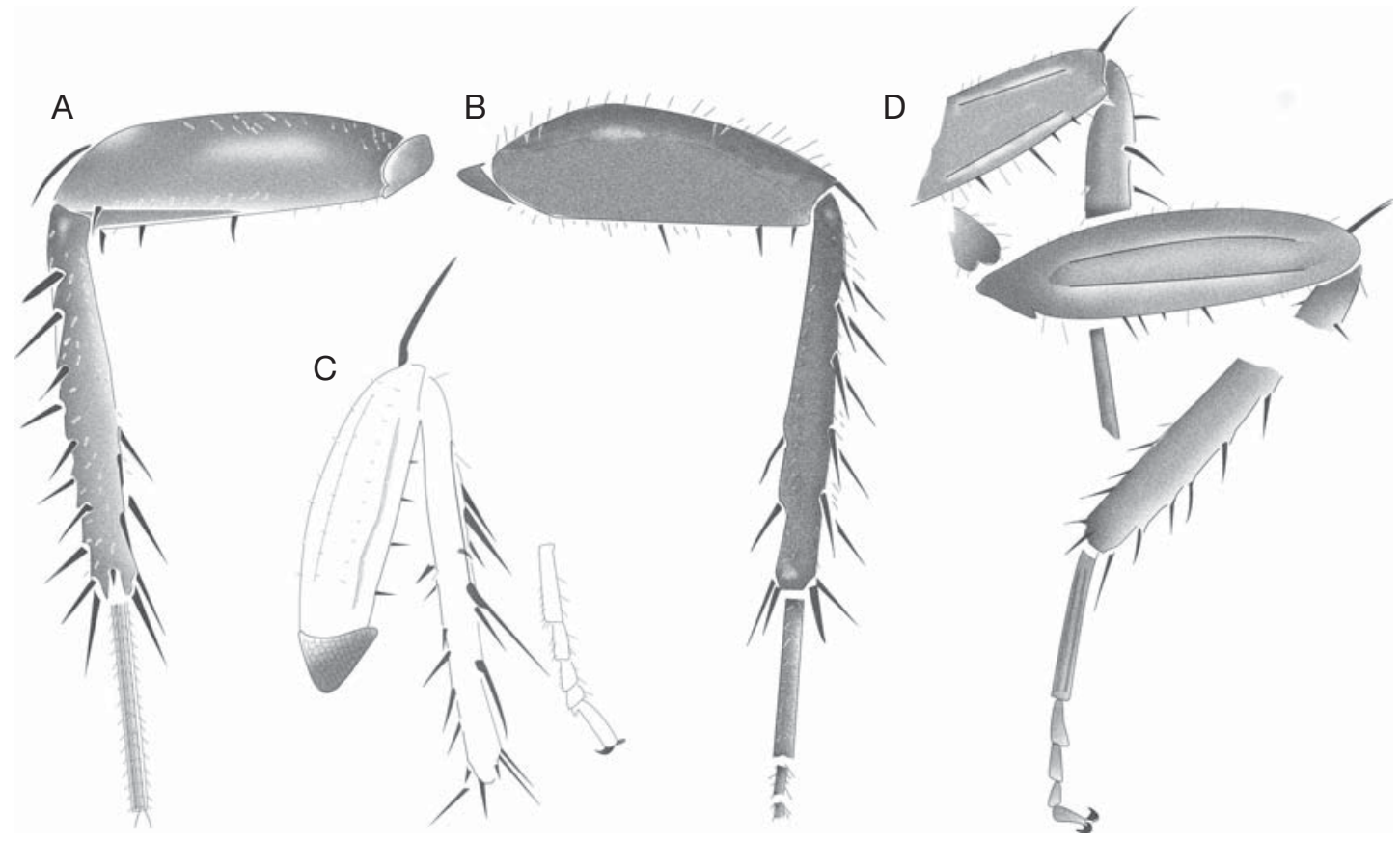

FIG. 7. - A, B, Batola nikolai n. gen., n. sp., ventral and dorsal views of the hind leg, ARC-57.2 (length of tibia 1,6 mm); C, hind leg of Globula lake n. gen., n. sp., ARC-263.14 (length of tibia 1,7 mm); D, undetermined Caloblattinidae, ARC-152.3 (length of tibia $2,3 \mathrm{~mm})$.

\section{DISCUSSION}

The present study indicates the strong dominance of the cosmopolitan family Blattulidae also in this amber assemblage and, according to the dominance of this family in the Cretaceous humid and warm assemblages, it represents a further support for the humid and warm source area of the Archingeay amber.

The present blattulid species Batola nikolai n. sp., unlike more common free living Elisama, displays characteristics of hidden habits within the forest litter, and supports the hypothesis that resin drops fell on the ground, additionally supported by the horizontal, rectangular in respect to specimen orientation, melting traces. The low diversity of this, at least partially, ground assemblage is thus surprising.

This state of preservation may be the cause for the low specific diversity of the amber material.
One might expect a higher diversity of decomposers in the denser vegetation possibly addicted with the amber-producing forests. While the familial and generic diversity is high, 17 specimens reveal only seven species, of which 10 specimens are Blattulidae, two Mesoblattinidae, and a single in Liberiblattinidae, Caloblattinidae, a new family Eadiidae n. fam., and two are unidentified. Liberiblattinidae are the most variable Mesozoic group of cockroaches, with all the known genera being monotypic, and thus the occurrence of the indigenous genus Leptolythica n. gen. is not surprising.

The taphonomy of complete specimens is also biased towards small individuals, and thus towards immatures. While in imprint Early Cretaceous record immatures comprise a very little portion (50:583 in Early Cretaceous of Baissa in Siberia [Vršanský 1997]; 3:511 specimens in the Early Cretaceous of Bon Tsagaan in Mongolia [Vršanský 


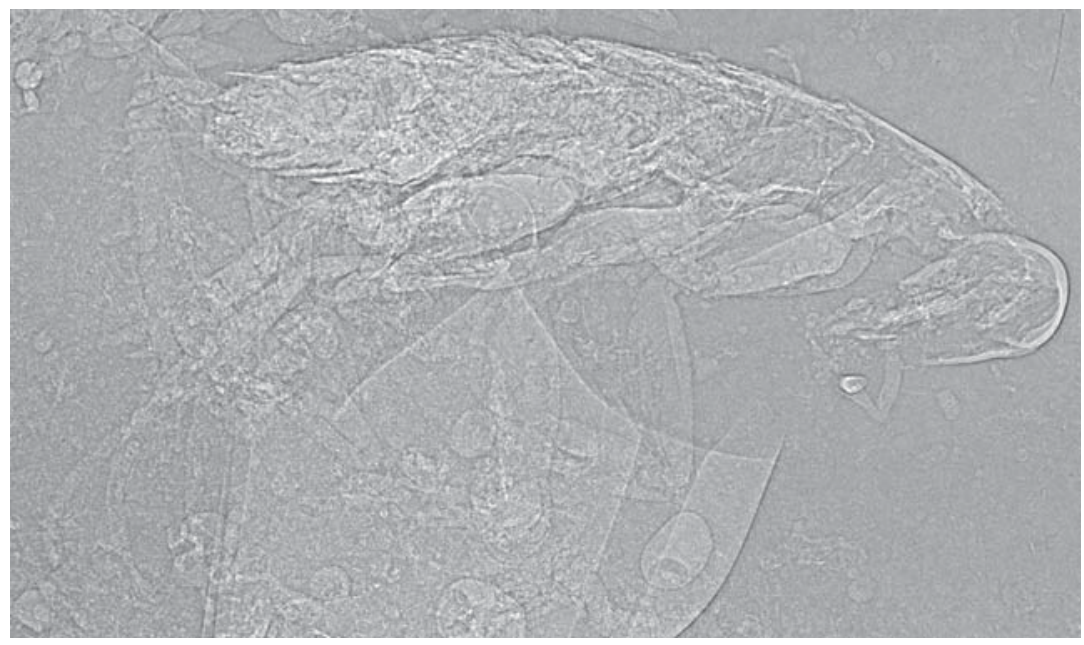

FIG. 8. - Specimen ARC-037b1, phase contrast microradiography showing immature Blattulidae Batola nikolai n. gen., n. sp. (Sivis odpo n. gen., n. sp. is not visible here). Length of the specimen $5.6 \mathrm{~mm}$ (courtesy of M. Lak and P. Tafforeau, ESRF Grenoble).

2003b]; 50:c. 3000 specimens in Late Jurassic of Karatau in Kazakhstan [Vršanský 2007]), in French amber this ratio is reverse (10:2), and in the Turonian New Jersey amber 4:2 (one is an isolated forewing) (unpublished). In addition to the complete specimens, one represents a damaged individual (pre- or post-burial damage), one is an exuvium and three represent isolated legs. The metrics of immatures suggest Blattulidae were developing with a few, less than six, number of instars. The high abundance of isolated legs may suggest autotomy, predation while captured, or leaving a leg in the amber during the death.

It is worth noting the reduction of pronotal length in at least two independent lineages of cockroaches in this locality. Such short pronota are unknown from the sedimentary record, and may be a result of free, active life with the improved visual orientation.

According to the relative abundance (of 760 identified arthropod specimens [Perrichot et al. 2007] 17 cockroaches are studied herein, comparing with seven of thousands specimens from the New Jersey amber and 17 out of several thousands specimens from the Lebanon amber [unpublished]), one may conclude the modern detritivore chains, similar to the ones of the living advanced ecosystems, has already been formed, which appears supported by the presence of termite-like cockroaches and termites. Nevertheless, the diversity of cockroaches was low, possibly as a result of the rather low diversity of plant types.

\section{Acknowledgements}

I thank Vincent Perrichot and Didier Néraudeau for organizing the study, and for preparation of preliminary documentation and specimens. I thank Alexandr Rasnitsyn, Dong Ren and an anonymous reviewer for revision of the manuscript. I also thank Malvina Lak (Université Rennes I, UMR CNRS 6118 and ESRF) and Paul Tafforeau (ESRF) for providing the reconstruction of specimens ARC037b using phase contrast synchrotron imaging. I also thank Lubka Puškelová for technical support. This work was supported by the project VEGA 6002 and 2/0125/09, MVTS; Literary Fund, and is a contribution to the Agence nationale de la Recherche (ANR) project AMBRACE no. BLAN071-184190. I thank the European Synchrotron Radiation Facility of Grenoble to the realization of the images and the access to the data. 

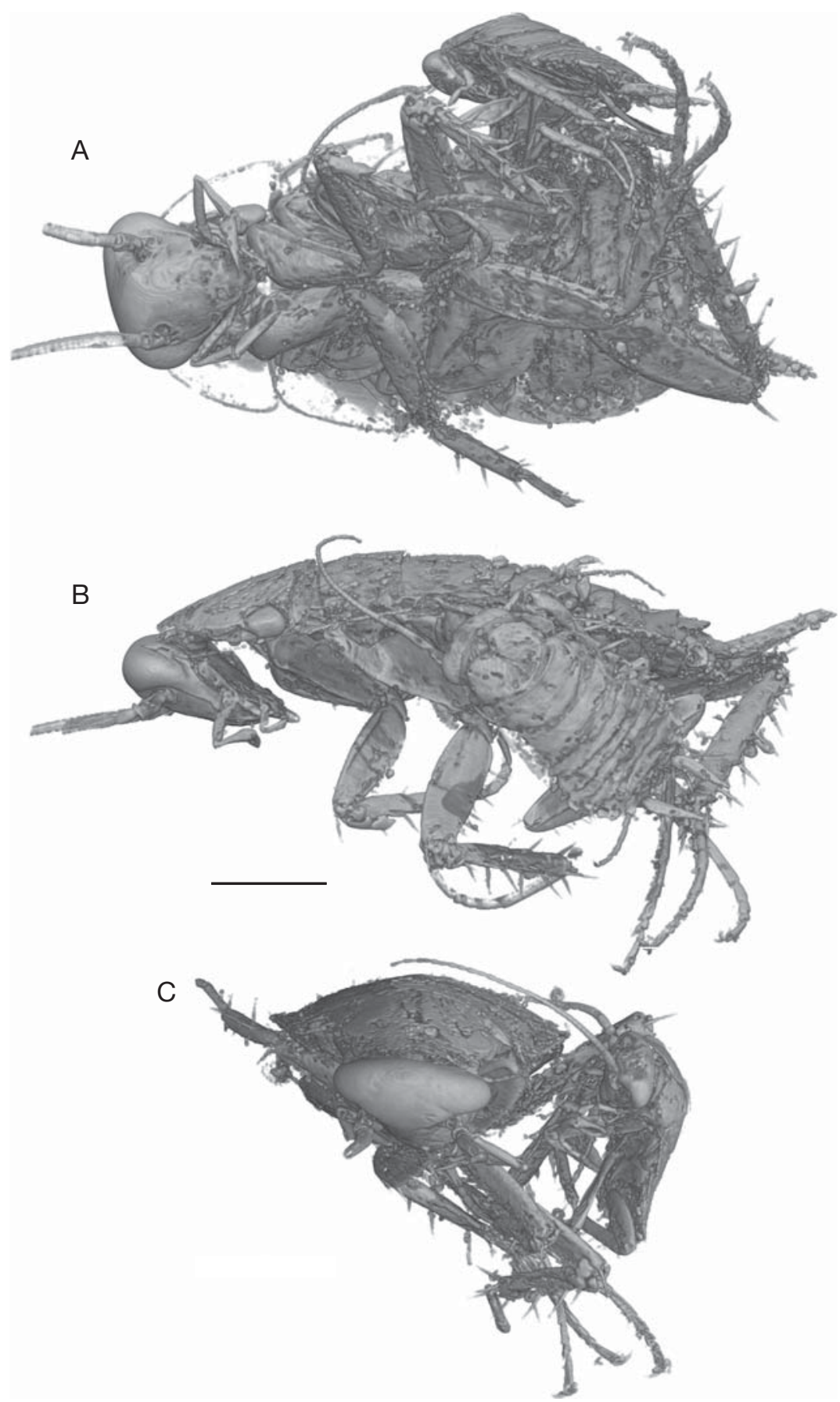

FIG. 9. - 3D virtual extraction of two immatures obtained by phase contrast microtomography (courtesy of M. Lak and P. Tafforeau, ESRF Grenoble), large specimen ARC-037b1: Batola nikolai n. gen., n. sp. (Blattulidae), small specimen ARC-037b2: Sivis odpo n. gen., n. sp. (Mesoblattinidae); A, ventral view; B, lateral view, C, frontal view. For details on the synchrotron imaging see Lak et al. (2008). Scale bar: $1 \mathrm{~mm}$. 

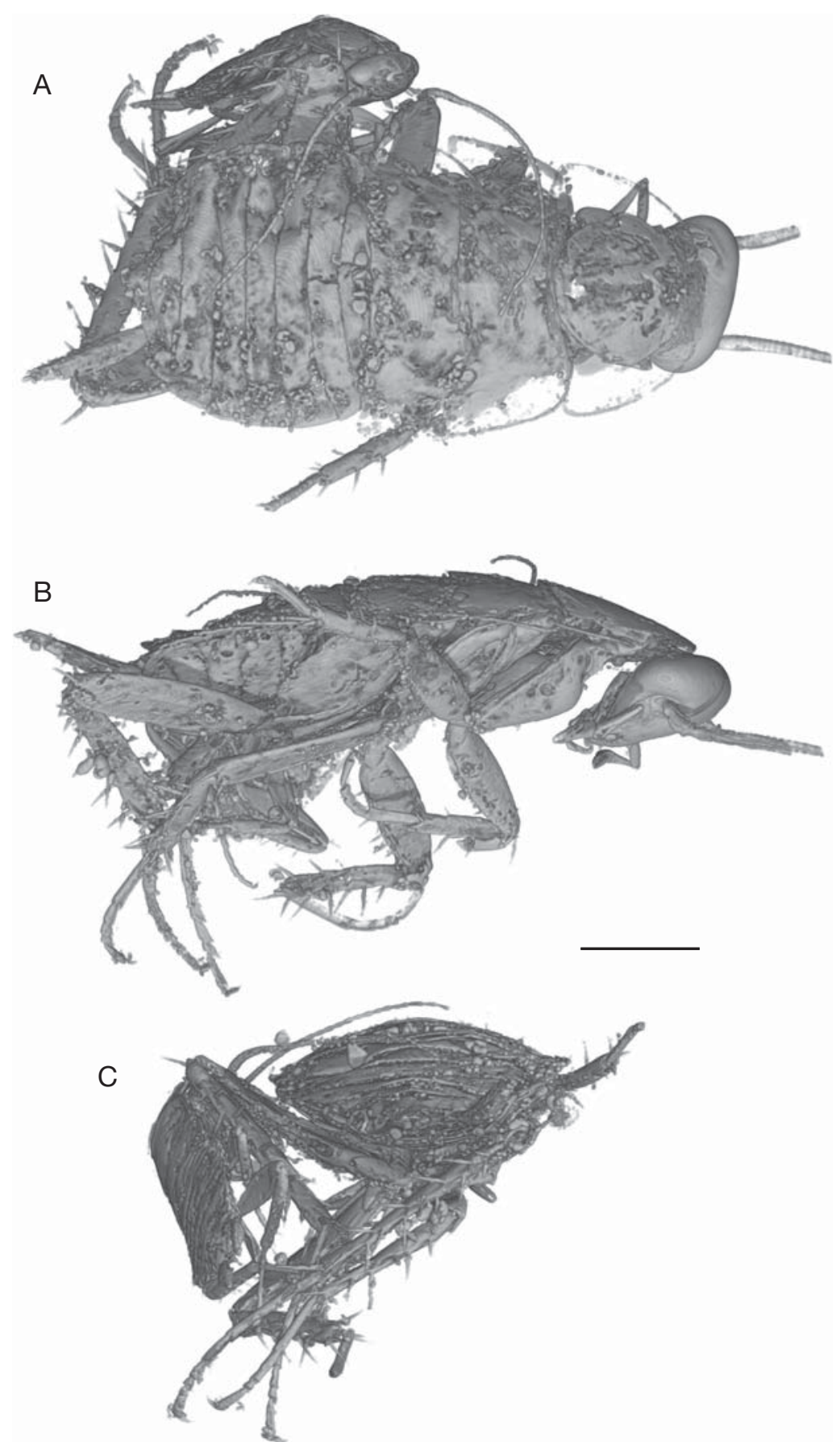

FIG. 10. - 3D virtual extraction of two immatures obtained by phase contrast microtomography (courtesy of M. Lak and P. Tafforeau, ESRF Grenoble), large specimen ARC-037b1: Batola nikolai n. gen., n. sp. (Blattulidae), small specimen ARC-037b2: Sivis odpo n. gen., n. sp. (Mesoblattinidae); A, dorsal view; B, lateral view, C, terminal view. Scale bar: $1 \mathrm{~mm}$. 


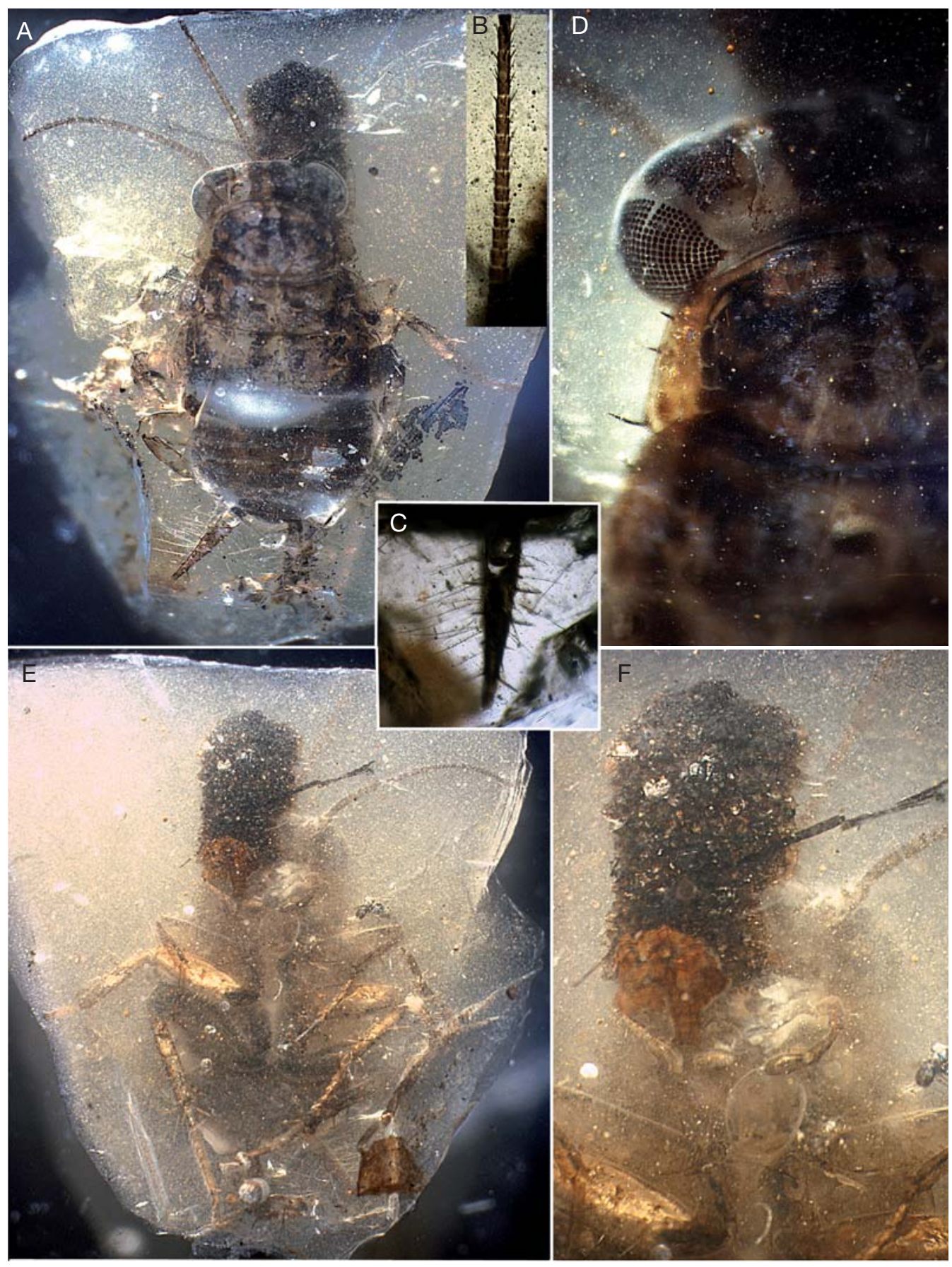

FIG. 11. - An immature of Batola nikolai n. gen., n. sp. (Blattulidae) feeding on strobillus, holotype ARC-254.4: A, dorsal view of complete specimen; B, detail of antenna; C, detail of cercus; $\mathbf{D}$, detail of head and pronotum; E, ventral view; $\mathbf{F}$, detail on the debris and mouthparts, ventral view. Length of the specimen $2.7 \mathrm{~mm}$. 


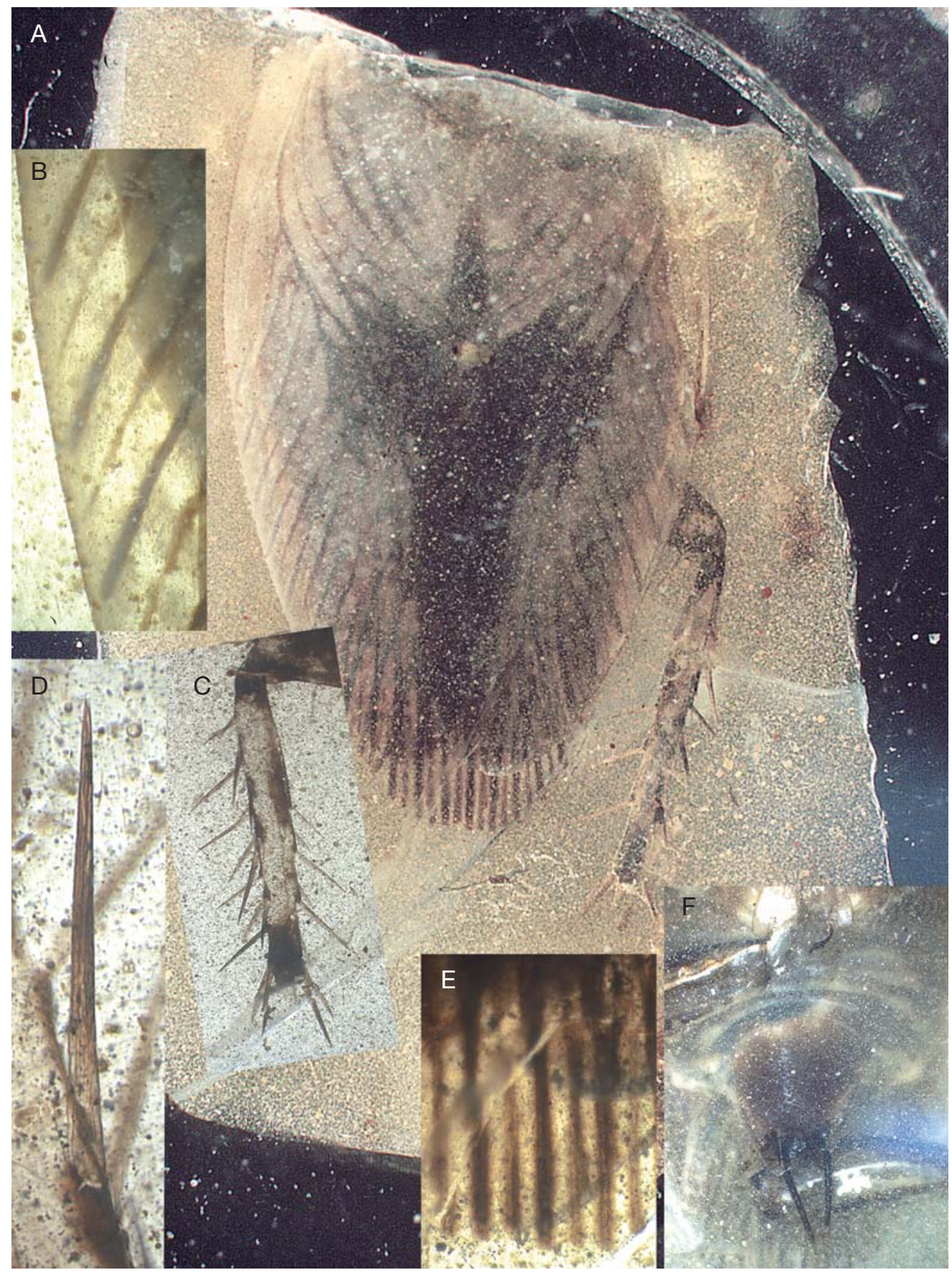

FIG. 12. - Batola nikolai n. gen., n. sp. (Blattulidae), specimen ARC-261.1: A, general habitus; B, detail of forewing venation in the radial area; $\mathbf{C}$, detail of left hind leg; $\mathbf{D}$, detail of a spur with longitudinal helical ridges; $\mathbf{E}$, detail of the hindwing venation; $\mathbf{F}$, detail of the terminalia, ventral view. Length of the wing $6.8 \mathrm{~mm}$. 


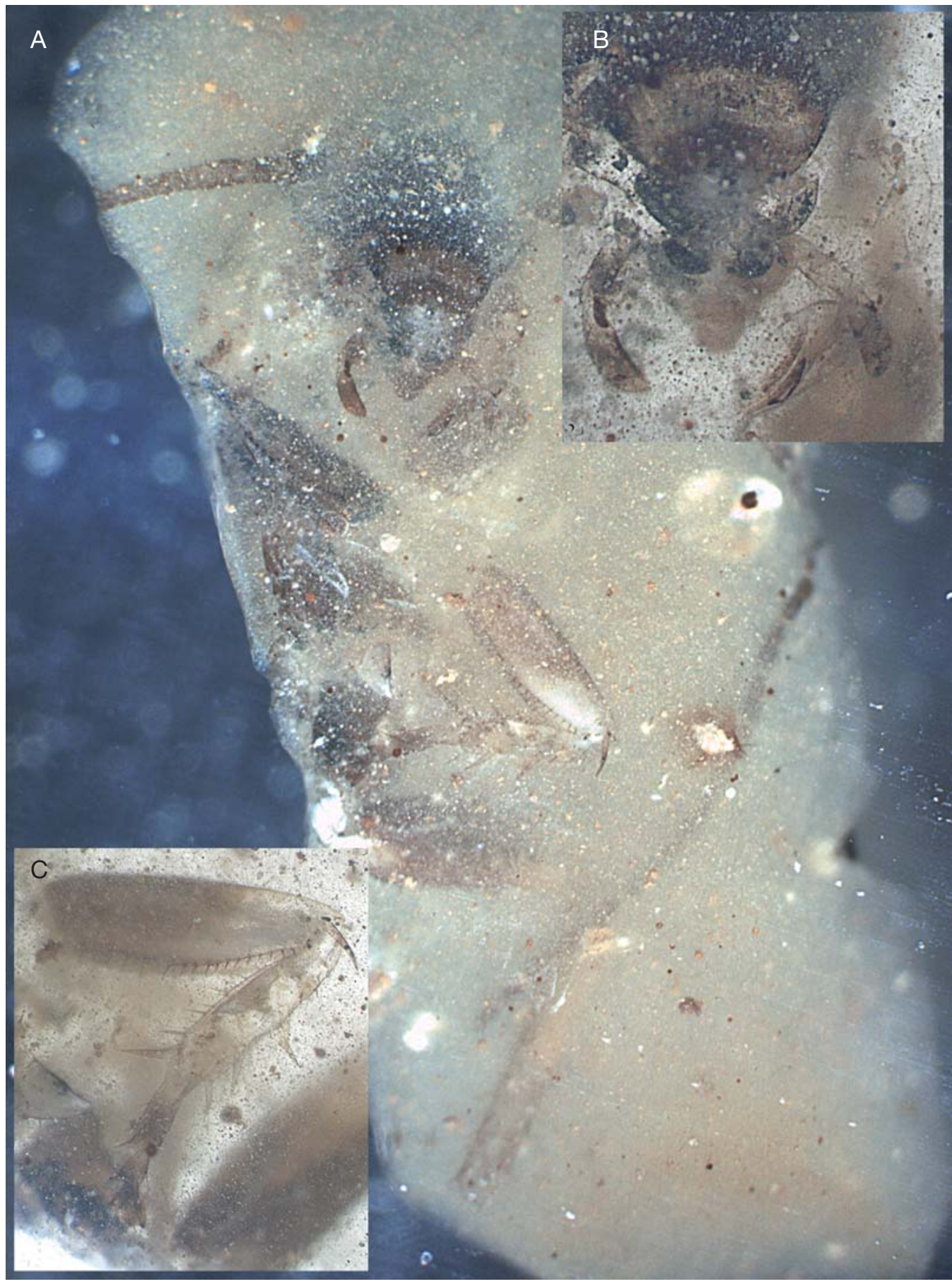

FIG. 13. - An immature of Leptolythica vincenti n. gen., n. sp. (Liberiblattinidae), holotype ARC-260.2: A, general habitus in ventral view, head width $1.14 \mathrm{~mm}$; $\mathbf{B}$, detail of mouthparts; $\mathbf{C}$, detail of fore leg. 


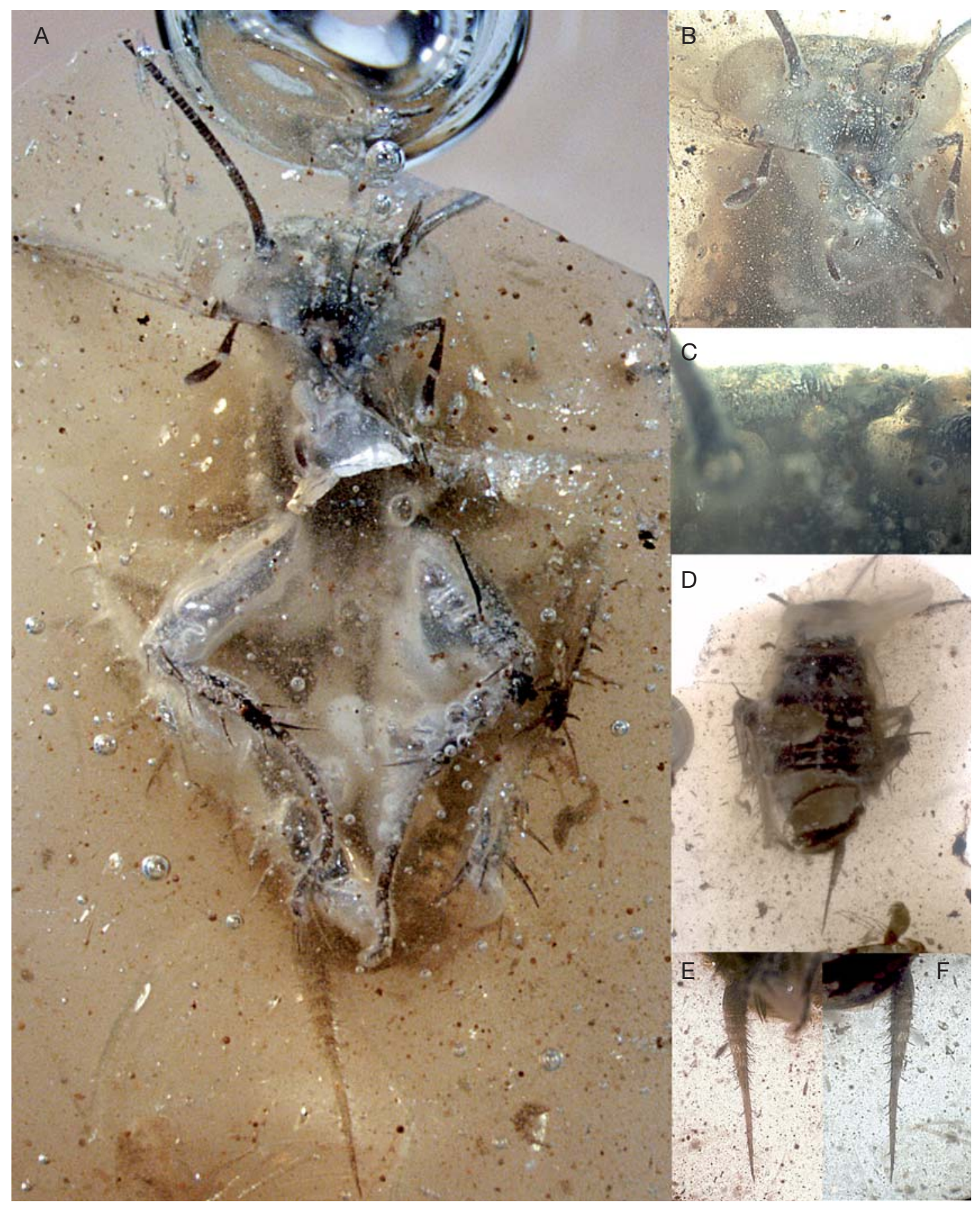

FIG. 14. - An immature of Eadia aidae n. gen., n. sp. (Eadiidae n. fam.), holotype ARC-263.16: A, ventral view, head width 1.9 mm; $\mathbf{B}$, detail of head; C, detail of the central ocellus; $\mathbf{D}$, dorsal view; $\mathbf{E}, \mathbf{F}$, ventral and dorsal views of the cercus. 


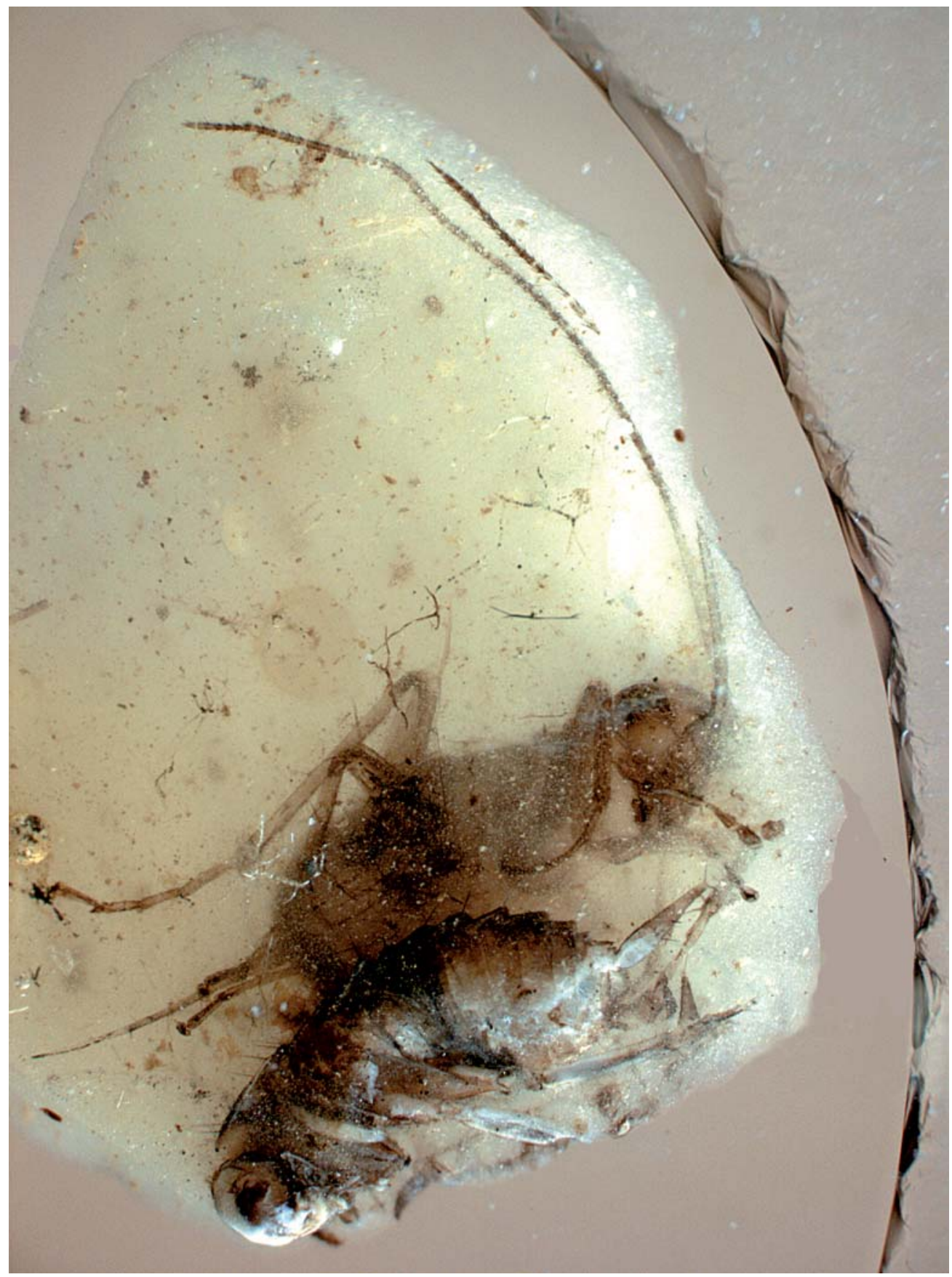

FIG. 15. - Immature of Globula lake n. gen., n. sp., holotype ARC-309.2 (left) and specimen of uncertain family. Distance between apexes of two heads $3.2 \mathrm{~mm}$. 

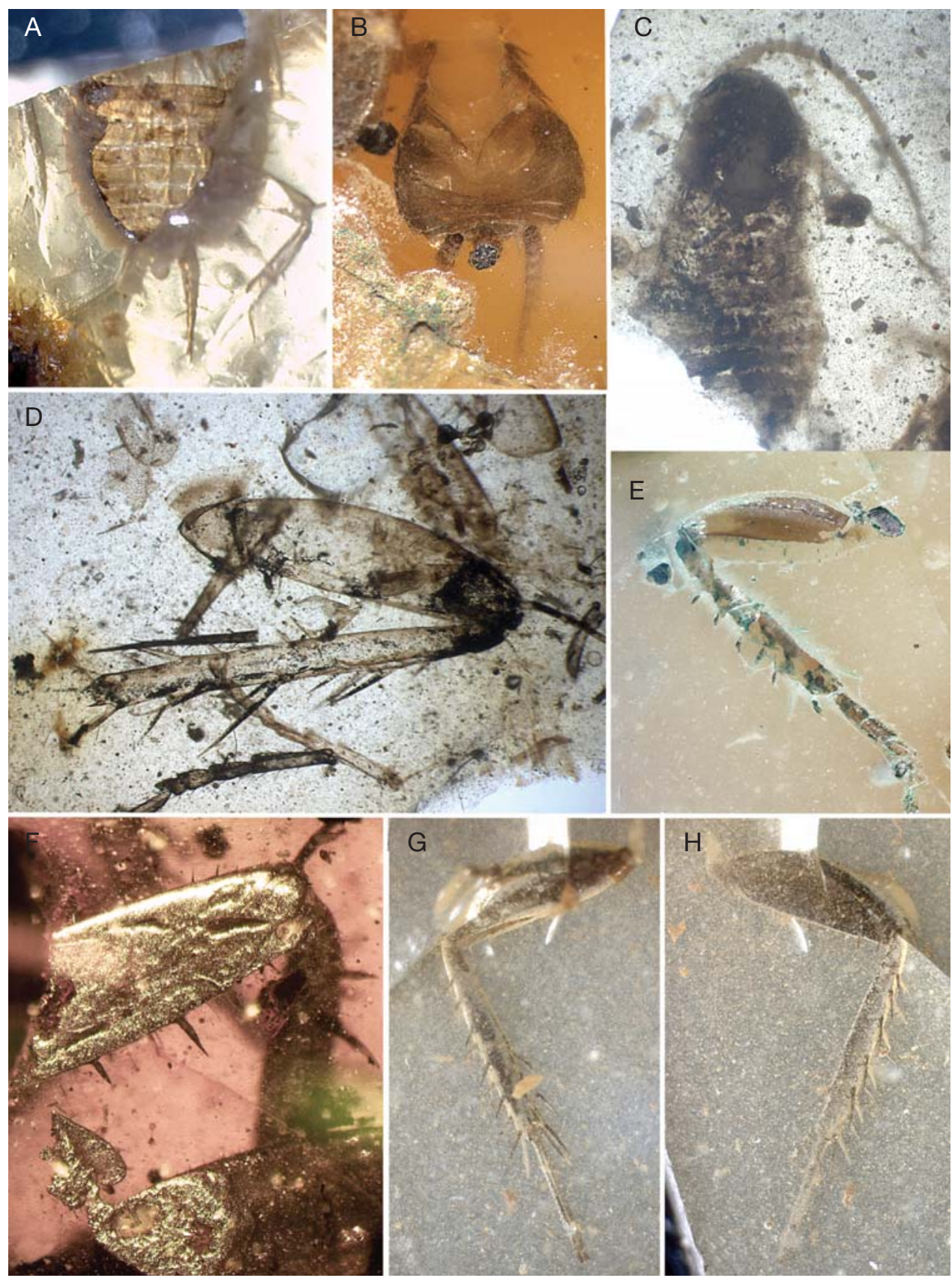

FIG. 16. - A, immature of Globula lake n. gen., n. sp. (Blattulidae), specimen ARC-60, dorsal view of complete specimen; B, immature of Batola nikolai n. gen., n. sp. (Blattulidae), ventral view of terminalia; C, immature of Sivis odpo n. gen., n. sp. (Mesoblattinidae), holotype ARC-89.2, dorsal view of complete specimen; D, leg of Globula lake n. gen., n. sp., specimen ARC-263.14; E, leg of B. nikolai n. gen., n. sp., specimen ARC-138; F, unidentified legs of Caloblattinidae, specimen ARC-152.3; G, H, leg of B. nikolai n. gen., n. sp., specimen ARC 57.2. 


\section{REFERENCES}

AnisyutKin L. N \& Gorochov A. V. 2008. - A new genus and species of the cockroach family Blattulidae from Lebanese amber (Dictyoptera, Blattina). Paleontological Journal 42 (1): 43-46.

Cifuentes-Ruiz P., VRŠanskÝ P., Vega F. J., CevallosFERriz S. R. S., GONZÁlEZ-Sorian E. \& DELGado DE JEsús C. R. 2006. - Terrestrial arthropods from the Cerro del Pueble Formation (Campanian Late Cretaceous), Difunta Group, NE Mexico. Geologica Carpathica 57 (5): 347-354.

Gorochov A.V. 2006. - New and little known orthopteroid insects (Polyneoptera) from fossil resins: Communication 1. Paleontological Journal 40 (6): 646-654.

GRIMALDI D. 2003. - A revision of Cretaceous mantises and their relationships, including new taxa (Insecta: Dictyoptera: Mantodea). American Museum Novitates 3412: 1-47.

Grimaldi D. A. \& Ross A. J. 2004. - Raphidiomimula, an enigmatic new cockroach in Cretaceous amber from Myanmar (Burma) (Insecta: Blattodea: Raphidiomimidae). Journal of Systematic Palaeontology 2 (2): 101-104.

HoNG Y. 1986. - New fossil insects from the Haifanggou Formation, Liaoning Provice. Journal of Jiling University (Earth Science Edition) 4: 10-16.

lak M., Néraudeau D., Nel A., Cloetens P., PerRICHOT V. \& TAFFOREAU P. 2008. - Phase contrast $\mathrm{X}$-ray synchrotron imaging: opening access to fossil inclusions in opaque amber. Microscopy and Microanalysis 14: 251-259.

Néraudeau D., Perrichot V., Dejax J., Masure E., Nel A., Philippe M., Moreau P., Guillocheau F. \& GUYOT T. 2002. - Un nouveau gisement à ambre insectifere et à végétaux (Albien terminal probable): Archingeay (Charente-Maritime, France). Geobios 35 (2): 233-240.

Perrichot V. 2004. - Early Cretaceous amber from south-western France: insight into the Mesozoic litter fauna. Geologica Acta 2: 9-22.

Perrichot V., Nel A. \& Néraudeau D. 2004. - Two new wedge-shaped beetles in Albo-Cenomanian ambers of France (Coleoptera: Ripiphoridae: Ripiphorinae). European Journal of Entomology 101: 577-581.

Perrichot V., Néraudeau D., Nel A. \& De PloëG G. 2007. - A reassessment of the Cretaceous amber deposits from France and their palaeontological significance. African Invertebrates 48 (1): 213-227.

VisHNIAKOVA V. N. 1968. - [Mesozoic cockroaches with an external ovipositor and pecularities of their reproduction (Blattodea)], in ROHDENDORF B. B. (ed.), [Jurassic Insects of Karatau]. Nauka, Moscow: 55-86 (in Russian).

VisHNiAKOVA V. N. 1973. — [New cockroaches (Insecta: Blattodea) from the Upper Jurassic of Karatau mountains], in NARCHUK E. P. (ed.), Problemy paleontologii nasekomych. Doklady na 24. ježegodnom ćtenii pamyati N. A. Kholodkowskogo (1-2 April, 1971), Leningrad: 64-77 (in Russian).

VRŠANSKÝ P. 1997. - Piniblattella gen. nov., the most ancient genus of the family Blattellidae (Blattodea) from the Lower Cretaceous of Siberia. Entomological Problems 28 (1): 67-79.

VRŠANSKÝ P. 2000. - Decreasing variability-from the Carboniferous to the Present! (Validated on independent lineages of Blattaria). Paleontological Journal 34 (suppl. 3): 374-379.

VRŠANSKÝ P. 2003a. - Umenocoleoidea - an amazing lineage of aberrant insects (Insecta, Blattaria). Amba projekty 7 (1): 1-32.

VRŠANSKÝ P. 2003b. - Unique assemblage of Dictyoptera (Insecta - Blattaria, Mantodea, Isoptera) from the Lower Cretaceous of Bon Tsagaan Nuur in Mongolia. Entomological Problems 33 (1-2): 119-151.

VRŠANSKÝ P. 2004. - Cretaceous Gondwanian cockroaches (Insecta, Blattaria). Entomological Problems 34 (1-2): 49-54.

VRŠANSKÝ P. 2007. — Jumping cockroaches (Blattaria, Skokidae fam. n.) from the Late Jurassic of Karatau in Kazakhstan. Biológia 62 (5): 588-592.

VRŠANSKÝ P. 2008a. - A complete larva of a Mesozoic (Early Cenomanian) cockroach (Insecta: Blattaria: Blattulidae) from the Sisteron amber (Alpes-de-Haute-Provence, SE France). Geologica Carpathica 59 (3): 269-272.

VRŠANSKÝ P. 2008b. - New blattarians and a review of dictyopteran assemblages from the Lower Cretaceous of Mongolia. Acta Palaeontologica Polonica 53 (1): 129-136.

VRŠANSKÝ P. \& ANSORGE J. 2007. — Lower Jurassic cockroaches (Insecta: Blattaria) from Germany and England. African Invertebrates 48 (1): 103-126.

VRŠANSKÝ P., QUICKE D. L. J., RASNITSYN A. P., BASIBUYUK H., Ross A., FitTON M. \& Vidlí̌Ka L'. 2001. - The oldest fossil insect sensilla. Amba projekty 4 (1): 1-8.

WANG T., LIANG J.-H. \& REN D. 2007a. - Variability of Habroblattula drepanoides gen. et. sp. nov. (Insecta: Blattaria: Blattulidae) from the Yixian Formation in Liaoning, China. Zootaxa 1443: 17-27.

Wang T., Liang J.-H., Ren D. \& Shi C. 2007b. — New Mesozoic cockroaches (Blattaria: Blattulidae) from Jehol Biota of western Liaoning in China. Annales Zoologici 57 (3): 483-495. 